\title{
What does a CEO of a firm in crisis do? Evidence from Finnish firms
}

\author{
Erkki K. Laitinen \\ Professor of Accounting \& Finance \\ Department of Accounting and Business Finance \\ University of Vaasa. POB 700, FIN-65101 Vaasa, Finland
}

\begin{abstract}
ACKNOWLEDGEMENTS
This study has been financially supported by The OP-Pohjola Group Research Foundation that is gratefully acknowledged.
\end{abstract}

\begin{abstract}
The objective is to analyze managerial work and the importance of information to CEOs, contrasting crisis firms with non-crisis firms. It is assumed that CEOs of firms in crisis address work and information differently than their counterparts in non-crisis firms. The study is based on a survey completed by 215 top Finnish managers (CEOs. The sample is classified on the basis of financial performance as crisis firms (31) and non-crisis firms (127), with firms of undefined status excluded. Managerial work is captured by Mintzberg's (1973) classification of work roles. The findings show that CEOs of crisis firms suffer from role ambiguity and tend to emphasize interpersonal and decisional roles less than their counterparts. They spend less time on long-term tasks and work less at their offices. CEOs of crisis firms also suffer from low availability of information and pay less attention to information from different sectors.
\end{abstract}

Keywords: Crisis firms; CEO behaviour; managerial work; Finnish firms

\section{INTRODUCTION}

Understanding the behavior of top managers in organizations on the verge of crisis is an important issue in management. It can help managers mitigate unfavorable behavior and the negative impacts of a threat, and even to avoid the final crisis. Therefore, many studies have addressed the behavior of management in declining organizations (Weitzel \& Jonsson, 1989; 1991; D’Aveni, 1989; D’Aveni \&MacMillan, 1990; Mellahi \& Wilkinson, 2004; Trahms, Ndofor \& Sirmon, 2013). Weitzel and Jonsson (1991) defined a declining organization as one that fails to anticipate, recognize, avoid, neutralize, or adapt to external or internal pressures that threaten long-term survival. They proposed five stages of organizational decline, namely, the blinded, inaction, faulty action, crisis, and dissolution stages. This study focuses on the crisis stage and the final stages before it occurs. This stage is marked by diminished resources and is a last chance for reorganization and reversal. The crucial question is whether an organization has sufficient resources and effective mechanisms to pursue a major reorganization (Weitzel \& Jonsson, 1991). This stage is very much stressed by a condition or event that threatens the survival of the organization (Starbuck, Greve \& Hedberg, 1978; D'Aveni \& MacMillan, 1990). This event can be declining demand, which often precedes organizational bankruptcy or failure (Hambrick \& D'Aveni, 1988). The resultant pressure leads management to behave in ways other than it would in a non-crisis organization. 
Different theories predict how senior managers will respond to a crisis (D'Aveni \& MacMillan, 1990; Mellahi \& Wilkinson, 2004), and the predictions often conflict. The threat-rigidity response and crisis-denial theories suggest that a crisis diverts a CEO's attention away from the locus of the crisis if it creates noise that prevents the CEO from considering relevant information about the source of the crisis (Kiesler \& Sproull, 1982). Environmental scanning and stress theories predict that a CEO will pay more attention to an (external) crisis because of the importance, immediacy, and uncertainty of the issue (Dutton, 1986). Mellahi and Wilkinson (2004) concluded that the field of organizational failure could become chaotic and result in a fragmentation trap in which researchers are faced with a multitude of conflicting and unorganized theories and findings. D'Aveni and MacMillan (1990) suggested that the conflict regarding predictions originates from the fact that managers in strong firms and those in failing firms facing a severe external crisis implement fundamentally different response patterns. They indicated that managers of failing firms react to crisis in the manner predicted by the decline, crisis-denial, and threat-rigidity response models. Managers of surviving firms tend to follow the patterns predicted by the environmental scanning and stress theories. D'Aveni and MacMillan identified an association only between output crisis and output focus in the responses of managers of survivor firms.

The scope of the present study is limited and compares managerial behavior in surviving crisis firms and non-crisis firms only. Accordingly, the study uses the environmental scanning and stress theories. The present study follows D'Aveni and MacMillan (1990) but extends their analysis in many ways. D'Aveni and MacMillan (1990) suggested that managers in non-crisis firms pay equal attention to internal and external environments and more attention to the output environment than the input environment. However, managers of surviving crisis firms pay more attention to the external environment. Thus, D'Aveni and MacMillan concentrated on the analysis of the locus of attention. The present study extends this research to analyze the work of managers in (surviving) crisis and non-crisis firms and their preferences for information.

In this study, managerial work is assessed by Mintzberg (1973) role typology with 10 different roles. It is suggested here that CEOs in crisis firms suffer from role ambiguity more than their counterparts in non-crisis firms. In addition, time horizon of tasks and location of work are investigated. The locus of attention is described by the importance and availability of different information sectors. D'Aveni and MacMillan (1990) analyzed the content of senior manager's letters to shareholders in annual reports as manifestations of the perceptual locus of attention. This study uses an Internet-based survey to map the managerial work of CEOs and their perceived importance of job-relevant information.

Consequently, the purpose of this study is to extend research on the behavior of senior managers in surviving crisis firms using a broad framework of managerial-work analysis. The study is based on the results of a survey completed by 215 Finnish senior managers (CEOs) from firms in different industries and of different sizes. The sample is classified on the basis of perceived financial performance into crisis firms (31) and non-crisis firms (127), with firms of undefined status excluded. The findings show that managers in crisis firms suffer more from role ambiguity and tend to emphasize interpersonal and decisional roles, especially Mintzberg's figurehead and leader roles, less than their counterparts in non-crisis firms. They also suffer from low availability of information and pay less attention to long-term tasks and information about customers, employees, and internal processes. Logistic regression analysis shows that a combination of managerial work and information variables efficiently discriminate between managers in crisis firms and their counterparts in non-crisis firms. Thus, 
CEOs in crisis and non-crisis firms behave in significantly different ways with respect to managerial work and attitudes toward information.

The present study contributes to theory and practice regarding managerial behavior in many ways. First, it is based on the sudden threat of the Great Recession, which provides unique circumstances to test a set of theoretical hypotheses on CEOs' behavior in crisis firms. Second, it provides a justified description of what CEOs of crisis firms are doing and where, and on what kind of information they are prioritizing. Third, the study applies Minzberg's managerialwork-role model to a new crisis situation, revealing important changes in behavior patterns. Fourth, the study clearly shows that the behavior of CEOs in crisis firms differs in many ways from that of CEOs in non-crisis firms. These differences can be used in practice to understand the behavior of top managers in different circumstances and determine different methods for preventing unfavorable behavior traits and enhancing favorable behavior traits. Although Finnish top managers have special characteristics regarding their leadership style and decision making, it is expected that the results can be generalized to most Western countries as they share similar cultures. The special characteristics of Finnish managers include hard (commanding and straightforward) leadership that is often described with the "Management by Damn" concept (Lämsä, 2010), which suggests solving problems in chaotic circumstances is normal for Finnish managers. Therefore, the impact of a crisis on the behavior of a CEO may be even more remarkable in countries other than Finland.

The rest of the paper is organized as follows. The second section reviews prior studies to extract research hypotheses. In total, seven research hypotheses on differences in the behavior of CEOs in crisis firms versus non-crisis firms are presented for empirical analysis. The third section presents the empirical data and statistical methods of the study while the fourth section analyses the results. Simple statistical methods (i.e., mean and median tests, partial correlations, and logistic regression analysis) are used to compare CEOs' managerial behavior in crisis and non-crisis firms. The fifth section discusses the empirical findings and provides a conclusion. It also discusses the limitations of the study and outlines topics for further research.

\section{PRIOR STUDIES AND RESEARCH HYPOTHESES}

\section{General framework for managerial work}

Managerial work is characterized by variety, fragmentation, and brevity. It includes a large number of tasks outside traditional planning, decision making, and evaluation. These tasks include activities such as negotiating, recruiting, training, innovating, and forms of contact peculiar to individual manager. These tasks are not carried out in an ordered and systematic way. Instead, managerial tasks are characterized by great variety, brevity, fragmentation in time and space, numerous interruptions, and encounters with others (Mintzberg, 1973; Kurke \& Aldrich, 1983; Tengblad, 2002; Hall, 2010). These tasks are flexible not only within the organizational environment but also for individual managers so their importance varies from manager to manager (Mintzberg, 1973; 1989). Personal factors such as values, experience, knowledge, competences, and mental models greatly determine how any manager approaches a given job (Mintzberg, 1994; Gottschalk, 2002). However, managerial work is also likely to be related to organizational and environmental factors (e.g., perceived environmental uncertainty (PEU), technology, organizational structure, strategy, and size) (Gottschalk, 2002; Grover, Jeong, Kettinger \& Lee, 1993).

The problem with analyzing what CEOs do is that there is no science to managerial work (Mintzberg, 1973). This means that senior managers do not work according to procedures that have been prescribed by scientific analysis. Mintzberg (1973), however, based his managerial- 
work analysis on the observation that all tasks in managerial work involve one or more of three basic behaviors-with their importance varying from manager to managerinterpersonal contact, processing of information, and making decisions. Several other studies have also found these basic characteristics (intrinsic conditions) of managerial work (Stewart, 1988; Kotter, 1982; Kurke \& Aldrich, 1983; Noordegraaf \& Stewart, 2000; Tengblad, 2002; 2006). Interpersonal roles are primarily concerned with interpersonal relationships and refer to managing through people. Informational roles focus on the information aspects of managerial work that link all such work and refer to managing by information. Decisional roles are concerned with decision making and refer to managing through action. The three role categories are closely associated with information: interpersonal roles provide information, informational roles process information, and decisional roles use information (Mintzberg, 1973).

Mintzberg (1973) defined the major dimensions of managerial work as consisting of 10 main roles (organized sets of behaviors) grouped into three categories according to their intrinsic conditions. This classification of roles is the best-known and most widely tested construct used to describe managerial work. The three categories and the 10 roles in this classification are: interpersonal roles (Figurehead; Leader; Liaison), informational roles (Monitor; Disseminator; Spokesman), and decisional roles (Entrepreneur; Disturbance Handler; Resource Allocator; Negotiator). Each role is different, reflects different management behaviors and can be described by a different set of tasks (Mintzberg, 1973). These 10 roles act as an integrated whole (a gestalt) and are not easily separated in managerial work. However, the emphasis placed by CEOs on different tasks within the roles varies strongly for different managers in different circumstances, leading to differences in information needs and in the importance ascribed to different forms of information. Table 1 shows the typical tasks for each managerial role as outlined by Mintzberg (Fox, 1992). The table includes 20 managerial tasks describing the 10 roles.

Table 1. Mintzberg's (1973) 10 work roles by three categories with exemplary tasks from Fox (1992)

\begin{tabular}{|l|}
\hline A. INTERPERSONAL CATEGORY OF ROLES \\
\hline 1. FIGUREHEAD \\
\hline Task 1: Present employees with prizes or certificates at ceremonies. \\
\hline Task 2: Represent the organization in outside bodies or at public functions. \\
\hline 2. LEADER \\
\hline Task 3: Conduct employment, disciplinary, or appraisal interviews. \\
\hline Task 4: Hold regular meetings with subordinates. \\
\hline 3. LIAISON \\
\hline Task 5: Regularly hold discussions with colleagues in other organizations. \\
\hline Task 6: Acknowledge mail from other organizations. \\
\hline B. INFORMATIONAL CATEGORY OF ROLES \\
\hline 4. MONITOR \\
\hline Task 7: Regularly make tours of inspection around workplace. \\
\hline Task 8: Meet fellow managers to discuss mutual problems. \\
\hline 5. DISSEMINATOR \\
\hline Task 9: Transmit information to subordinates or other appropriate persons in organization. \\
\hline Task 10: Hold review sessions regarding information with subordinates or other appropriate persons. \\
\hline 6. SPOKESMAN \\
\hline Task 11: Regularly hold discussions with own supervisor or Board. \\
\hline
\end{tabular}




\begin{tabular}{|l|}
\hline Task 12: Act as expert or spokesman for section or organization. \\
\hline C. DECISIONAL CATEGORY OF ROLES \\
\hline 7. ENTREPRENEUR \\
\hline Task 13: Supervise design and implementation of organizational projects. \\
\hline Task 14: Seek opportunities in environment to initiate improvements in organization. \\
\hline 8. DISTURBANCE HANDLER \\
\hline Task 15: Adjudicate sudden conflicts (over many issues) among subordinates. \\
\hline Task 16: Hold strategy sessions when problems arise that threaten section or organization. \\
\hline 9. RESOURCE ALLOCATOR \\
\hline Task 17: Set program and/or budget for section or organization and review regularly. \\
\hline Task 18: Schedule work program and review and change as needed. \\
\hline 10. NEGOTIATOR \\
\hline Task 19: Represent section or organization at negotiations with outside groups such as unions or suppliers. \\
\hline Task 20: Negotiate changes in contracts or commitments with outsiders. \\
\hline
\end{tabular}

\section{Managerial-role emphasis and ambiguity}

Managers emphasize the importance of work roles differently according to personal, organizational, and environmental factors. The relevant work roles tend to remain quite stable for CEOs in stable circumstances. Mintzberg (1973) called these roles organized sets of behaviors: they vary depending on the particular CEO but are reasonably stable over time. However, a CEO's emphasis on managerial work roles can be expected to change when circumstances around the firm change. The general argument of this study is that a CEO's emphasis on work roles changes when a firm enters states of decline, distress, and, finally, crisis. Weitzel and Jonsson (1991) concluded that an organization in decline fails to anticipate, recognize, avoid, neutralize, or adapt to external or internal pressures that threaten long-term survival. There are five stages of organizational decline, namely the blinded, inaction, faulty action, crisis, and dissolution stages (Weitzel \& Jonsson, 1991).

The boundaries of these stages are not exact, and different stages can occur at different times in different declining organizations. In this study, the focus is on the crisis stage and the distress stages of the process that occurs just before this stage. Weitzel and Jonsson (1991) stated that an organization is initially blind to the early stages of decline, then recognizes the need for change but fails to take action. Finally, it takes action; however, if the action taken is inappropriate, the organization reaches a point of crisis and may be forced to dissolve if the process continues. Thus, this process can be described as increasing distress that culminates in the final stages. The crisis stage is characterized by diminished resources and can be described as a last chance for reorganization and reversal. D'Aveni and MacMillan (1990) defined crisis as any event or condition that threatens the survival of an organization. An example of crisis is declining or stagnant demand, which frequently precedes organizational bankruptcy (Hambrick \& D'Aveni, 1988). Crisis is often associated with circumstances in which there is little time to react and the threat is unanticipated (Staw, Sandelands \& Dutton, 1981). In this study, crisis or serious distress is empirically associated with a sudden decline in demand originating from the Great Recession.

If an organization is already in the inaction stage, uncertainty about internal problems makes it more difficult to gain agreement from managers about the direction in which the firm should move. Without strong commitment, there is insufficient organizational power to implement difficult decisions (Thompson, 1967). In the inappropriate action stage, there is a necessity for change in the process of decision making and the implementation of decisions (Kaufman, 1985). Leadership is questioned, and individual leaders are subjected to increasing stress. 
Leaders are forced by circumstances to consider substantive changes and can no longer defend the goals and methods appropriate for a business-as-usual phase (Starbuck, Greve \& Hedberg, 1978). Schendel, Patton and Riggs (1976) referred to this stage as the introduction of new leadership. When an organization reaches the crisis stage, it has unsuccessfully attempted to deal with its problems, which will have resulted in crisis, chaos, procrastination, efforts to go back to basics, change, and anger (Levy, 1986:13). It is here that an organization reaches a critical point in its history and must undergo major reorientation and revitalization or suffer failure. The prescription for recovery from crisis is instituting a major reorganization and turnaround. Revolutionary changes in structure, strategy, personnel, and ideology are necessary (Hedberg, Nystrom \& Starbuck, 1976). A lack of action will precipitate certain failure (Weitzel \& Jonsson, 1991).

In summary, the adaptive responses to a situation that challenges or threatens an organization's survival, leading to increasing distress, are expected to result in increased stress for a CEO during the last stages of decline (cf. Staw, Sandelands \& Dutton, 1981). This adaptation causes CEOs to continuously question and adjust their emphasis on managerial work roles. Therefore, a general behavioral hypothesis is suggested that CEOs' emphasis on work roles in crisis firms significantly differs from CEOs' emphasis on work roles in non-crisis organizations. This hypothesis (H1) is as follows:

Hypothesis H1: Emphasis on managerial work roles differs between CEOs in crisis firms and CEOs in non-crisis firms.

The inaction and faulty action stages of an organization decline before a crisis, a factor that gives rise to questions over the roles of CEOs. It is expected that continuous questioning and reorientation of the emphasis on different work roles increases CEOs' role ambiguity, which refers to uncertainty regarding aspects of their roles (Kahn, Wolfe, Quinn, Snoek \& Rosenthal, 1964). Role ambiguity is problematic, especially for CEOs in declining or distressed organizations, because the resulting unfavorable personal outcomes (stress, lower levels of performance) are likely to prove disadvantageous to survival and to further worsen the difficult situation in which a crisis organization operates (Marginson, 2006). The second research hypothesis accordingly suggests that the degree of role ambiguity is higher for CEOs in crisis firms than their counterparts in non-crisis firms. This hypothesis (H2) is as follows:

Hypothesis H2: The degree of work-role ambiguity is higher for CEOs in crisis firms than for CEOs in non-crisis firms.

\section{Emphasis on the three role categories}

When an organization enters the final stages of decline, its CEO will experience increased stress due to the firm's financial distress. The typical symptoms of stress behavior are social withdrawal or a person isolating himself from a group (cf. Staw, Sandelands \& Dutton, 1981; Weiss, 1983). This kind of behavioral symptom can be characterized by a fear of social or performance situations in which a CEO has a personal contact with subordinates fearing for their future, or indeed with the firm's board. However, at the same time, CEOs can receive important social support from their colleagues and other managers (Weiss, 1983). These stress symptoms (such as social withdrawal) indicate that the importance of interpersonal roles (information providing) as perceived by CEOs decreases during the final stages of decline. The second important symptom of stress behavior in this context is indecisiveness, evident when CEOs have the power to determine an outcome but are not able to reach a conclusion (inaction stage). In the final stages of decline, indecisiveness magnifies the stress on CEOs because difficult decisions must be made simultaneously to avoid failure. This kind of situation is 
expected to lead to a reduction in the perceived importance of decisional roles (information use).

The outcome of the emphasis of informational roles is not as obvious. Increased uncertainty in the context of crisis can affect the importance of informational roles in many ways. It can increase the importance of these roles (information processing) because CEOs must identify opportunities, detect and interpret problem areas, and implement strategic or structural adaptations (Daft, Sormunen \& Parks, 1988). However, threats can also result in the overload of communication channels and restriction of information processing, diminishing the importance of informational roles. It is also possible that psychological stress can even freeze CEOs' behavior, leading to them persevering with well-learned courses of action (Staw, Sandelands \& Dutton, 1981). Because of the mixed potential consequences of crisis, a null hypothesis that the importance of informational roles does not change due to distress or crisis is proposed. In summary, the following hypotheses (H3a-c) are suggested for each category of managerial roles:

Hypothesis H3a: Emphasis on interpersonal roles for CEOs in crisis firms is lower than for CEOs in non-crisis firms.

Hypothesis H3b: Emphasis on decisional roles for CEOs in crisis firms is lower than for CEOs in non-crisis firms.

Hypothesis H3c: Emphasis on informational roles does not differ between CEOs in crisis firms and CEOs in non-crisis firms.

\section{Time Horizon and Place of Work}

It is expected that distress alters the time horizon of managerial tasks accomplished by CEOs. In the management hierarchy, CEOs are expected to focus on strategic tasks with a long-term time horizon. In reality, CEOs spend little time on strategic tasks and are subject to constant interruptions. They hold face-to-face meetings and move quickly from topic to topic (Mintzberg, 1975). The task agendas that CEOs carry in their heads may contain dozens of items on which they are working at the same time (Carroll \& Gillen, 1984). Mintzberg (1979) summarized that CEOs are driven to focus on current, tangible work even though the complex problems facing many organizations call for reflection and a far-sighted perspective.

Tengblad (2002) concluded that the view of CEOs as strategic actors should be balanced by an emphasis on the difficulties of navigating in a complex environment. In this environment, CEOs are challenged to deal with the pressures of superficiality by giving serious attention to the issues requiring it (Mintzberg, 1975). In the final stages of organizational decline, limits on CEOs' time and attention guarantee that all issues will not be attended to equally (Dutton, 1986). Threatening and acute issues act as catalysts to action by raising particular issues' priority. Thus, CEOs' prioritization of tasks during the final stages of a crisis is expected to move from long-term time-horizon tasks toward short-term time-horizon tasks (Smart \& Vertinsky, 1977; D’Aveni, 1989; D’Aveni \& MacMillan, 1990). Accordingly, the following hypothesis (H4) is suggested:

Hypothesis H4: CEOs in crisis firms give less time to long-term horizon tasks than CEOs in non-crisis firms.

Crisis is also expected to influence the places where CEOs conduct their work. Tengblad (2002) showed that CEOs spend their working hours primarily (31\%) in their own offices or elsewhere in their firms. This result is different to some degree but consistent with the results 
of Carlson's (1951) older study (41\%). However, when an organization enters the final stages of decline, the CEO's increasing stress and ever more limited time might diminish time spent in the office for several reasons. First, stress is often associated with loss of concentration, which makes it difficult for CEOs to focus on desk work and creates pressure to work outside the firm in spite of tension regarding social withdrawal. Second, outside the office, CEOs can search for social support when meeting colleagues and other managers. Third, taking care of the threatening and acute issues associated with crisis can force CEOs out of their offices. Drucker (2005) described a CEO's work in the following terms:

The CEO is the link between the Inside that is the organization, and the Outside of society, economy, technology, markets, and customers. Inside there are only costs. Results are only on the outside.

In the final stages of decline, CEOs can be strongly oriented toward results, which means they are strongly inclined to work away from the firm. Therefore, it is expected that CEOs in crisis firms spend less time in the office than CEOs in non-crisis firms, which leads to the following hypothesis (H5):

Hypothesis H5: CEOs in crisis firms spend less time in the office than CEOs in non-crisis firms.

\section{Importance of information}

The role of information in adaptive response to crisis or distress is central since information is the first link in the chain of perception and actions that permit an organization to adapt (cf. Daft, Sormunen \& Parks, 1988). CEOs are responsible for adaptation but have limited time and capacity to implement it and must choose between different information sectors. The threatresponse model argues that stress changes CEOs' information-processing patterns and generates increased search behavior, which can result in information overload (Staw, Sandelands \& Dutton, 1981; D’Aveni \& MacMillan, 1990). This confusion can hide the real cause of crisis, which makes CEOs restrict their information sectors and turn their attention to simplistic efficiency concerns such as identifying lower-cost inputs and finding ways to use internal resources differently (D'Aveni \& MacMillan, 1990). Thus, restriction of the information perspective can lead CEOs to rely on internal hypotheses and prior expectations and direct their attention to dominant or central cues and away from peripheral cues (Staw, Sandelands \& Dutton, 1981).

Consequently, CEOs in crisis firms are expected to place less importance on information about the output environment (customer needs, growth of demand) and more importance on input and the internal environment than CEOs in non-crisis firms do (in this context, it is also possible that psychological stress can even cause a CEO to freeze, as in fail to act.) Staw, Sandelands and Dutton (1981) noted that for some crisis firms, emphasizing input can be enough to save the firm from failure. However, this type of response is risky and can lead to failure when demand declines. The crisis firms in this study were confronted by a sudden decline in demand but in most cases were survivors. The behavior of a CEO in a surviving crisis firm can significantly differ from that found in a failing crisis firm. For the most part, the sample firms are small businesses, which often have inadequate information systems (Lybaert, 1998). Therefore, an important cause of crisis in small firms may be lack of information rather than information overload.

When a small firm with inadequate information systems is faced with a sudden decline in demand, there are three important perspectives of information (central cues) where the CEO's attention should be directed. First, financial information plays a central role in many stages of 
decline and should stimulate a CEO to pay attention to adaptation (Argenti, 1976; Weitzel \& Jonsson, 1991). Second, decline in demand results in information about how customers play a central role. In fact, customer needs and demand growth rates are the two most frequently identified critical success factors (D'Aveni \& MacMillan, 1990). Third, the main problem of coping with declining demand is associated with adaptation to declining demand in terms of employees, with the potential use of reorganization, dismissals, and redundancies (Greenhalgh, Lawrence \& Sutton, 1988). These kinds of adaptive actions can have serious consequences for employee motivation and firm performance. Therefore, information on employees is critical in this stage.

In summary, it is assumed that CEOs in crisis firms suffer from a lack of financial, customer, and employee information more than CEOs in non-crisis firms. Furthermore, it is suggested that this lack of information is associated with the lower importance placed by CEOs on these information sectors. If it is deemed of low importance, such information is not available when a firm becomes distressed and enters the crisis stage. Accordingly, the following hypotheses (H6 and H7) are proposed:

Hypothesis H6: CEOs in crisis firms assign financial, customer, and employee information less importance than CEOs in non-crisis firms.

Hypothesis H7: CEOs in crisis firms suffer from a lack of financial, customer, and employee information more than CEOs in non-crisis firms do.

\section{Empirical data}

\section{EMPIRICAL DATA AND STATISTICAL METHODS}

Empirical data for the present study on managerial work are based on an Internet-based survey conducted in January 2009. Statistical sampling was based on a data bank provided by Fonecta Finder, a Finnish operator that maintains an electronic telephone directory of Finnish businesses. Moreover, this directory includes email addresses of key people in firms. Using information in the data bank, firms outside the scope of the study were excluded. First, as the study deals with managerial work roles and the systematic use of information, firms were required to have more than 10 employees in the previous year, which is the lower size limit to indicate a firm has sufficiently organized management processes to merit having a CEO. Thus, (originally) micro firms were excluded from the sample: however, the number of employees in many crisis firms dipped below the limit of 10 in the crisis years 2008 and 2009. Second, the sample was restricted to limited liability companies, which, according to the Limited Liability Companies Act (LLCA) in Finland, must have a CEO. Third, the sample includes only firms with an email address for a CEO listed in the Fonecta data bank.

The final population included 11,790 firms, and $10 \%$ were randomly selected so that the sample comprised 1,179 limited companies. However, for technical reasons, it was not possible to reach 119 firms so the final sample was of 1,060 limited liability companies. A cover letter with a link and password to a web page containing the questionnaire was sent to the email address of the CEO of each firm. To ensure the reliability of responses and to complement the data, the data collection process included an option to later record and check responses. Three follow-up emails were sent, and after eight weeks, 222 firms (20.24\%) responded to the questionnaire. Because of missing values, seven questionnaires were excluded from the later analysis, and thus the final sample comprised 215 firms, which corresponds to a response rate of $20.0 \%$. The sample firms represent different industries: $31.1 \%$ are service firms while $25.3 \%$ and $16.3 \%$ belong to the manufacturing and trade industries, respectively. In general, the firms are small businesses and about 73.8\% have less than 50 employees. The sample also 
includes a few firms (5.5\%) with more than 500 employees. The size distribution is skewed and is consistent with the size distribution among limited liability companies in Finland.

The research time period provides us with an excellent opportunity to investigate the effect of sudden decline in demand on the adaptation of business firms. The 2008 financial crisis produced a significant economic shock to the global economy. This crisis first touched the U.S. financial sector in 2007, but the effects spread to several national economies, resulting in what has often been called the Great Recession. The shockwaves from the crisis were sorely felt in Finland in general and among the CEOs in the sample firms. First, a sharp decrease in GDP ($2.4 \%$ ) was observed in the last quarter of 2008 and continued through the first quarter of 2009. In 2009, GDP fell by $8.5 \%$, a decline that matched that of 1918 , when Finland was in the middle of a civil war. Because crisis is the consequence of a sudden threat, the beginning of the Great Recession provides unique potential for crisis research. In Finland, the recession continued for years and changed the business environment of firms. Accordingly, a similar survey on the effects of a sudden shock could not be undertaken in the current unfavorable but stable circumstances.

The questionnaire survey was conducted in January 2009, which was in the middle of the worst period of shock. The questionnaire asked CEOs to assess the overall performance of their firm in comparison with its most important competitors using 7-point Likert scales. The concept of overall performance was defined as the ability to generate profit, to grow, and to maintain liquidity and solvency at a sufficient level. On the Likert scale, 1 reflected a much worse ability, 4 about the same ability, and 7 a much better ability than that reported by a firm's most important competitors. The crisis group of firms included those that assessed their performance on this scale as 1-3 and the control group included those that assessed their performance as 5-7. Firms with undefined status (4) were excluded. Accordingly, there were 31 crisis firms and 127 non-crisis firms. It should be noted that non-crisis firms were also exposed to threats; however, they adapted to the circumstances and did not enter the crisis process.

Table 2. Median values of financial ratios for crisis and non-crisis firms

\begin{tabular}{|lr|r|r|r|r|r|r|r|}
\cline { 2 - 9 } \multicolumn{1}{c|}{} & \multicolumn{4}{c|}{ Crisis firms (median) } & \multicolumn{3}{c|}{ Non-crisis firms (median) } \\
\hline Financial ratio & 2008 & 2009 & 2010 & 2011 & 2008 & 2009 & 2010 & 2011 \\
\hline Return on investment & 7.800 & & 9.90 & 10.3 & $20.050^{*}$ & & & 13.0 \\
ratio (\%) & 0 & 6.400 & 0 & 00 & $* *$ & $12.500^{*}$ & 10.300 & 00 \\
\hline & - & - & & & & & & \\
Growth in net sales (\%) & 0.100 & 10.10 & 10.5 & 3.50 & $10.300^{*}$ & & & 8.40 \\
& 0 & 0 & 00 & 0 & $*$ & -6.000 & 4.450 & 0 \\
Quick ratio & 0.900 & & 1.10 & 1.50 & $1.500^{* *}$ & & & 1.30 \\
\hline & 0 & 1.000 & 0 & 0 & $*$ & $1.500^{* *}$ & 1.400 & 0 \\
Equity ratio (\%) & 24.90 & 26.05 & 26.0 & 35.9 & $44.850^{*}$ & $45.100^{*}$ & 44.600 & 46.9 \\
$* *$ & 00 & 0 & 00 & 00 & $* *$ & $* *$ & 00 \\
\hline
\end{tabular}

Note:

p-value of 2-tailed Mann-Whitney U test: ${ }^{* * *}=\mathrm{p}<0.01$; $^{* *}=\mathrm{p}<0.05$; $^{*}=\mathrm{p}<0.1$

It is important that performance assessment by CEOs was self-reported as this shows that the crisis firms had passed at least the first stage of organizational decline, the blinded stage, and entered the final stages of distress and crisis. However, to avoid any common method bias, it was important to validate the firms' performance using other sources of information. Therefore, the financial situation of firms in the two groups was assessed by objective measures using financial statement analysis for several years during and after the survey date, 
ending in 2014. Table 2 shows the median values of return on investment ratio (ability to generate profit), growth rate in net sales (ability to grow), quick ratio (liquidity), and equity ratio (solvency). The figures show that, on average, crisis firms in 2008 consistently suffered from low profitability, declines in sales, low liquidity, and low solvency, all of which are typical financial signs of crisis. In 2008, the four indicators were all statistically significantly lower for the crisis firms than for the non-crisis firms. However, in 2010, the crisis firms began to recover and grow very quickly. In 2011, the differences in the ratios between the groups were no longer significant. For the most part, the crisis firms were declining but not failing organizations. By 2012, two of the 31 crisis firms (6.5\%) had gone bankrupt while only one of the $127(0.8 \%)$ non-crisis firms had, meaning that almost all the firms are survivors.

\section{Variables}

\section{Managerial-role emphasis and role ambiguity}

The measurement of survey variables is described in Appendix 1. In this study, the managerial work of CEOs was measured by the perceived importance of the role tasks presented by Mintzberg (1973). This classification of roles is the best-known and most widely tested construct used to describe managerial work. The description of the 10 roles is based on a brief summary of the basic tasks conducted by CEOs in these roles. In the present survey, the work roles are examined using the typical tasks delineated by Mintzberg. There are two tasks for each role for a total of 20 tasks. The 20 managerial tasks used in the questionnaire are the same as those presented in Table 1. The survey tool employed was successfully used by Fox (1992). The survey tool assesses the importance of tasks with questions that ask CEOs to rate how important they consider each of the 20 tasks within their managerial work using a 7-point Likert scale anchored with not important at all (1) and extremely important (7).

The construct of managerial work is used to measure CEOs' emphasis on different work roles: the higher the importance ascribed to a task, the stronger the emphasis on the task. This same construct is also used to measure role ambiguity. Hall (2008) measured a corresponding concept (role clarity) by asking respondents to indicate on a 7-point Likert scale anchored with very uncertain (1) and very certain (7) the extent of their certainty about aspects of their job. In this study, the importance of CEOs' top role tasks is used to reflect role clarity or, inversely, role ambiguity: the higher the average importance of the most important tasks, the lower the role ambiguity. Mintzberg's role categories were developed to cover all intrinsic characteristics common to managerial work of all CEOs. If a CEO does not perceive any of these roles as important, his or her role ambiguity is regarded as high. For assessing ambiguity, the average importance of the five most important tasks to the CEO is calculated.

\section{Time horizon and place of work}

The time horizon of tasks conducted by CEOs describes the time dimension of managerial work, which is assumed to change in the final stages of crisis. Following the standard concepts of planning, the questionnaire first classifies managerial tasks into the following three categories: operational tasks, tactical tasks, and strategic tasks. These tasks differ from each other in their organizational scope and time horizon. Strategic tasks focus on broad and longlasting issues. For these tasks, the time horizon set in the questionnaire is over three years. Tactical tasks are more specific and limited, with a medium-term scope specified as one to three years. Operational tasks are associated with carrying out short-term activities and have a short-term scope. These tasks are specified to correspond to annual work plans with a timespan from one month to one year. The questionnaire also includes an additional category of tasks: daily, routine tasks with a time horizon of less than one month. Thus, the question concerning the time horizon for managerial tasks encompasses four categories (0-1 month; 1 month-1 year; 1-3 years; more than 3 years). CEOs were also asked to assess the average 
amount of working time they spent conducting tasks in these four categories using a 7-point Likert scale anchored with none at all (1) and extremely much (7)

The place where work is conducted concerns the physical location of CEOs' work. There are different ways to measure this dimension of work. Tengblad (2002) registered work during an investigation period and divided it by the number of regular working days (cf. Carlson, 1951). In this study, CEOs were asked to assess the average amount of working time they spent in different physical locations using a 7-point Likert scale anchored with none at all (1) and a very great deal (7). Five alternative physical locations were presented for selection, mainly following Tengblad's alternatives: the CEO's own office; elsewhere inside the firm; business travel or business visits outside the firm; working at home; and elsewhere outside the firm. Tengblad (2002) also included an alternative for transportation that was excluded from the present set of alternatives. This construct allows us to compare CEOs' working time in different locations for crisis and non-crisis firms.

\section{Importance of information}

In the real world, the sources and forms of information that CEOs use are diverse and numerous. Therefore, systematization of the characteristics of information is required to connect CEOs' managerial work with the importance of information. In this study, the concept of the information perspective is used to capture the characteristics of job-relevant information. The information perspective describes sectors of information, such as the balanced scorecard (BSC) (Kaplan \& Norton, 1992). The idea of the BSC is to provide a powerful set of information to top managers to help them carry out their tasks (Ittner \& Larcker, 1998). The information perspective may include a large set of sectors. For example, the BSC was originally built from four sectors: financial, customer, internal process, and learning and growth (Kaplan \& Norton, 1992). However, recent studies have indicated that these four sectors do not capture all sectors relevant to top managers (Chenhall, 2005; Ittner, Larcker \& Meyer, 2003). Other research also suggests the sectors may not be properly justified and sufficient to cover all strategically important areas (Norreklit, 2000), which has led managers to add information sectors such as one concerning employees.

Seven different sectors of information available to CEOs were included in the questionnaire. Similar to the aims of the BSC, this variety of sectors refers here to sectors of information that together form a powerful set of information and give CEOs a comprehensive view of their business (Kaplan \& Norton, 1992). The perspective is divided into seven sectors that include the four original BSC sectors (financial, customer, internal processes, and innovation and learning perspectives) and three additional sectors (supplier, competitor, and employee perspectives). The perceived importance of information from these sectors was assessed by CEOs using a 7-point Likert scale anchored with not important (1) and extremely important (7) that reflects the perceived importance of each sector to their managerial work. In addition to importance, the availability of information from different sectors for CEOs to use in their managerial work was mapped by the same seven sectors and measured using a 7-point Likert scale anchored with not available at all (1) and very good availability (7) ).

\section{Contextual and personal variables}

For the cross-sectional analysis, it was important that the crisis and non-crisis firms were as similar as possible with respect to the variables that can affect the issues under investigation. These variables can be classified as contextual or organizational variables (environment and organization) and personal (CEO) variables. Many studies have shown that contextual or organizational variables can affect CEOs' managerial work and their attitudes toward information (Pfeffer \& Salancik, 1978; Grover, Jeong, Kettinger \& Lee, 1993; Gottschalk, 2002; 
Hall, 2010). Managerial work and the importance of information also vary according to the approach of the particular CEO. This means that different CEOs emphasize different things in different ways in their work. Thus, personal factors such as values, experience, knowledge, competences, and mental models influence how CEOs approach their jobs (Stewart, 1982; Mintzberg, 1994; Gottschalk, 2002).

In this study, a large set of variables was used to check the differences between crisis and noncrisis firms in order to investigate comparability. This set includes as contextual or organizational variables measures for size, industry, strategy, PEU, level of competition, horizontal and vertical structure of the organization, formalization, family ownership and management, and exports (cf. Chenhall, 2003 for contingency variables). The strategy of firms was assessed along two different typologies: the generic strategies of Porter (1980) (cost leadership, differentiation, and focus strategies) and the market strategies of Miles and Snow (1978) (prospector, analyzer, and defender (PAD) strategies). The personal characteristics of CEOs were mapped by a set of four variables: gender, age, experience, and level of education. The measurement of the contextual and personal variables is explained in detail in Appendix 1.

\section{METHODS}

The seven research hypotheses (H1-H7) were tested using the F-test statistic to compare the expected values of the target variables between crisis and non-crisis groups of firms under the null hypothesis that they are equal. Because only the crisis and non-crisis firm groups were compared to each other, $F=t 2$, where $t$ is Student's $t$ statistic. In addition, the equality of expected values of background variables with a skewed distribution (such as financial ratios) or an ordinal scale was tested by the Mann-Whitney U test, which is a nonparametric test of the null hypothesis that the populations of crisis and non-crisis firms are the same. Some of the main results were also tested by partial correlations between a crisis-group dummy variable and the variables under investigation, controlled for a set of control variables (contextual and personal variables).

The test of the research hypotheses was based on assumed univariate differences in the expected values of research variables between the crisis and non-crisis firm groups. In addition, to these separate analyses, logistic regression analysis was used as a multivariate method to investigate the efficiency of several variables together and discriminate between the two groups. This method is useful because it does not require that independent variables are multivariate normal or that groups have equal covariance matrices as required for traditional discriminant analysis (Hosmer \& Lemeshow, 1989). The logistic regression model to determine the conditional probability of belonging to the crisis firm group can be expressed as follows:

$$
p(Y=1 \mid X)=\frac{1}{1+e^{-L}}=\frac{1}{1+e^{-\left(b_{0}+b_{1} x_{1}+. .+b_{n} x_{n}\right)}}
$$

Where $\mathrm{Y}=1$ and refers to the crisis status of a firm observation, $\mathrm{X}$ is the matrix of independent variables, $\mathrm{L}$ is the logit, and bi $(\mathrm{i}=0,1 \ldots \mathrm{n})$ are coefficients for the independent variables $\mathrm{xi}(\mathrm{i}=$ $1,2, \ldots, n)$. The independent variables $X$ were selected through a stepwise procedure based on forward conditional selection from the set of research variables.

The goodness of the model was assessed by standard tests $(-2$ log information measure, Cox \& Snell R2, and Nagelkerke R2). The significance of the coefficients was tested by the Wald test, and the linearity of logit was tested by the Hosmer-Lemeshow test. The classification accuracy of the model was assessed by the frequencies of Type I and Type II classification errors. In addition, the accuracy ratio (AC) was extracted from the receiver operating characteristic 
(ROC) curve. AC was calculated as $2(\mathrm{~A}-0.5)$, where $\mathrm{A}$ is the area under the ROC curve. If $\mathrm{AC}=1$, the accuracy of the model is perfect; if $\mathrm{AC}=0.5$, the accuracy of the model is average; if $\mathrm{AC}=0$, the model is random.

\section{Contextual and personal variables}

\section{EMPIRICAL RESULTS}

Table 3 shows statistics for the large set of contextual variables in the crisis and non-crisis firm groups used to investigate the similarity of firms. The crisis firms as a group had a median size smaller than that of the non-crisis firms but a larger average size, indicating high skewness in the size distribution. However, the firms in both groups are on average very small and thus comparable in terms of size. The industrial sector distributions do not significantly differ between the firm groups and thus do not distort comparability. However, there are differences in the generic strategies adopted: crisis firms more frequently adopted a focus strategy than non-crisis firms. Because all firms were faced with the 2008 economic downturn, this finding may indicate that firms using a focus strategy (concentration on a narrow market niche) are more vulnerable to sudden decline in demand than firms using a cost leadership or differentiation strategy.

In addition, crisis firms more frequently adopted the defender market strategy than non-crisis firms. This kind of strategy (defending existing products or markets) may, under conditions of threat, further increase vulnerability to a sharp decline in demand. The most statistically significant difference between crisis and non-crisis firms was found in the level of PEU: CEOs in crisis firms perceive higher PEU than CEOs in non-crisis firms. This is an expected finding since crisis creates uncertainty (Hall \& Mansfield, 1971). Crisis firms also tend to suffer from higher levels of competition. However, the difference in this variable is not statistically significant. The centralization of authority in crisis firms also exceeds that in non-crisis firms, which is a typical response to threat (Staw, Sandelands \& Sutton, 1981). In summary, there are some significant differences in contextual variables between the groups that may affect the issues under investigation. Some of the differences are, however, logical consequences of the crisis.

Table 3. Descriptive statistics of organizational variables

\begin{tabular}{|c|c|c|c|c|c|c|c|c|}
\hline \multirow[b]{2}{*}{ Organizational variable } & \multicolumn{3}{|c|}{ Crisis firms } & \multicolumn{3}{|c|}{ Non-crisis firms } & \multirow[b]{2}{*}{$\begin{array}{l}\text { Statist } \\
\text { ic } \S\end{array}$} & \multirow[b]{2}{*}{$\begin{array}{l}\mathrm{p}- \\
\text { valu } \\
\mathrm{e}\end{array}$} \\
\hline & Mean & $\begin{array}{l}\text { Std. } \\
\text { Dev. }\end{array}$ & $\begin{array}{l}\text { Medi } \\
\text { an }\end{array}$ & Mean & $\begin{array}{l}\text { Std. } \\
\text { Dev. }\end{array}$ & $\begin{array}{l}\text { Medi } \\
\text { an }\end{array}$ & & \\
\hline Number of employees in 2008 & 129.9 & 423.6 & 8.5 & 68.7 & 176.0 & 18.0 & $\begin{array}{r}619.0 \\
00 \\
\end{array}$ & $\begin{array}{r}0.17 \\
8\end{array}$ \\
\hline employees i & 115.3 & 350.2 & 13.0 & 80.6 & 196.7 & 19.0 & $\begin{array}{r}682.5 \\
00\end{array}$ & $\begin{array}{r}0.26 \\
5\end{array}$ \\
\hline Net sales in 2008 & $\begin{array}{r}3193 \\
4.2 \\
\end{array}$ & $\begin{array}{r}13963 \\
2.3 \\
\end{array}$ & $\begin{array}{r}1006 \\
.8 \\
\end{array}$ & $\begin{array}{r}1759 \\
6.9 \\
\end{array}$ & $\begin{array}{r}5498 \\
4.2 \\
\end{array}$ & $\begin{array}{r}2099 \\
.0 \\
\end{array}$ & $\begin{array}{r}1410 . \\
500 \\
\end{array}$ & $\begin{array}{r}0.09 \\
0 \\
\end{array}$ \\
\hline Net sales in 2009 & $\begin{array}{r}2182 \\
5.9 \\
\end{array}$ & $\begin{array}{r}80020 \\
.1\end{array}$ & $\begin{array}{r}912 . \\
0\end{array}$ & $\begin{array}{r}1805 \\
4.7 \\
\end{array}$ & $\begin{array}{r}5524 \\
9.8 \\
\end{array}$ & $\begin{array}{r}2308 \\
.5 \\
\end{array}$ & $\begin{array}{r}985.0 \\
00 \\
\end{array}$ & $\begin{array}{r}0.02 \\
4 \\
\end{array}$ \\
\hline $\begin{array}{l}\text { Percentage of manufacturing } \\
\text { firms }\end{array}$ & 0.226 & 0.425 & 0.0 & 0.299 & 0.460 & 0.0 & $\begin{array}{r}1824 . \\
000\end{array}$ & $\begin{array}{r}0.41 \\
8 \\
\end{array}$ \\
\hline $\begin{array}{l}\text { Percentage of retail and } \\
\text { wholesale firms }\end{array}$ & 0.129 & 0.341 & 0.0 & 0.181 & 0.387 & 0.0 & $\begin{array}{r}1866 . \\
000 \\
\end{array}$ & $\begin{array}{r}0.49 \\
1 \\
\end{array}$ \\
\hline Percentage of service firms & 0.290 & 0.461 & 0.0 & 0.315 & 0.466 & 0.0 & $\begin{array}{r}1920 . \\
000 \\
\end{array}$ & $\begin{array}{r}0.79 \\
1 \\
\end{array}$ \\
\hline $\begin{array}{l}\text { Percentage of cost leadership } \\
\text { generic strategy }\end{array}$ & 0.129 & 0.341 & 0.0 & 0.165 & 0.373 & 0.0 & $\begin{array}{r}1897 . \\
000 \\
\end{array}$ & $\begin{array}{r}0.62 \\
0 \\
\end{array}$ \\
\hline
\end{tabular}




\begin{tabular}{|c|c|c|c|c|c|c|c|c|}
\hline $\begin{array}{l}\text { Percentage of differentiation } \\
\text { generic strategy }\end{array}$ & 0.355 & 0.486 & 0.0 & 0.528 & 0.501 & 1.0 & $\begin{array}{r}1628 . \\
500\end{array}$ & $\begin{array}{r}0.08 \\
6\end{array}$ \\
\hline $\begin{array}{l}\text { Percentage of focus generic } \\
\text { strategy }\end{array}$ & 0.484 & 0.508 & 0.0 & 0.299 & 0.460 & 0.0 & $\begin{array}{r}1605 . \\
000\end{array}$ & $\begin{array}{r}0.05 \\
2\end{array}$ \\
\hline $\begin{array}{l}\text { Percentage of prospector } \\
\text { market strategy }\end{array}$ & 0.194 & 0.402 & 0.0 & 0.268 & 0.445 & 0.0 & $\begin{array}{r}1822 . \\
500\end{array}$ & $\begin{array}{r}0.39 \\
6 \\
\end{array}$ \\
\hline $\begin{array}{l}\text { Percentage of defender market } \\
\text { strategy }\end{array}$ & 0.226 & 0.425 & 0.0 & 0.118 & 0.324 & 0.0 & $\begin{array}{r}1756 . \\
500 \\
\end{array}$ & $\begin{array}{r}0.12 \\
2 \\
\end{array}$ \\
\hline $\begin{array}{l}\text { Percentage of analyzer market } \\
\text { strategy }\end{array}$ & 0.419 & 0.502 & 0.0 & 0.512 & 0.502 & 1.0 & $\begin{array}{r}1786 . \\
500 \\
\end{array}$ & $\begin{array}{r}0.35 \\
7 \\
\end{array}$ \\
\hline $\begin{array}{l}\text { Level of } \quad \text { perceived } \\
\text { environmental uncertainty\& }\end{array}$ & 4.500 & 1.075 & 4.0 & 3.835 & 0.833 & 4.0 & $\begin{array}{r}13.75 \\
9 \\
\end{array}$ & $\begin{array}{r}0.00 \\
0 \\
\end{array}$ \\
\hline $\begin{array}{l}\text { Level of } \\
\text { competition\& }\end{array}$ & 5.170 & 1.177 & 5.0 & 4.900 & 1.268 & 5.0 & 1.062 & $\begin{array}{r}0.30 \\
4 \\
\end{array}$ \\
\hline Level of decentralization\& & 3.060 & 1.340 & 3.0 & 3.650 & 1.179 & 4.0 & 5.735 & $\begin{array}{r}0.01 \\
8\end{array}$ \\
\hline $\begin{array}{l}\text { Number of decision-making } \\
\text { levels\& }\end{array}$ & 2.740 & 1.316 & 3.0 & 2.810 & 1.021 & 3.0 & 0.101 & $\begin{array}{r}0.75 \\
1 \\
\end{array}$ \\
\hline $\begin{array}{l}\text { Importance of following top } \\
\text { management's orders\& }\end{array}$ & 5.100 & 1.423 & 6.0 & 5.200 & 1.054 & 5.0 & 0.194 & $\begin{array}{r}0.66 \\
0\end{array}$ \\
\hline Percent of family firms & 0.621 & 0.494 & 1.0 & 0.598 & 0.492 & 1.0 & $\begin{array}{r}1800 . \\
500 \\
\end{array}$ & $\begin{array}{r}0.38 \\
9 \\
\end{array}$ \\
\hline $\begin{array}{l}\text { Degree of owner involvement } \\
\text { in managementa }\end{array}$ & 5.610 & 2.860 & 7.0 & 6.100 & 2.288 & 7.0 & 1.029 & $\begin{array}{r}0.31 \\
2\end{array}$ \\
\hline ercent of ex & 3.030 & 2.601 & 2.0 & 2.500 & 1.963 & 2.0 & $\begin{array}{r}1770 . \\
500 \\
\end{array}$ & $\begin{array}{r}0.36 \\
7 \\
\end{array}$ \\
\hline
\end{tabular}

Note:

$\S=$ 2-tailed Mann-Whitney U

test

$\&=$ F statistic (ANOVA): 7 -step Likert scale: from $1=$ very low to $7=$ very high

$a=$ F Statistic (ANOVA): 7 -step scale: $0=$ no involvement at all. $100=$ management is entirely in the owners' hands $(1=0 ; 2=1-20 ; 3=21-40 ; 4=41-60 ; 5=61-80 ; 6=81-99 ; 7=100)$

Table 4. Descriptive statistics of personal variables

\begin{tabular}{|c|c|c|c|c|c|c|c|c|}
\hline \multirow[b]{2}{*}{ Personal variable } & \multicolumn{3}{|c|}{ Crisis firms } & \multicolumn{3}{|c|}{ Non-crisis firms } & \multirow[b]{2}{*}{$\begin{array}{l}\text { U } \\
\text { statisti } \\
\mathrm{c} £\end{array}$} & \multirow[b]{2}{*}{$\begin{array}{l}\mathrm{p}- \\
\text { value }\end{array}$} \\
\hline & Mean & $\begin{array}{l}\text { Std. } \\
\text { Dev. }\end{array}$ & $\begin{array}{l}\text { Media } \\
\mathrm{n}\end{array}$ & $\begin{array}{l}\text { Mea } \\
\mathrm{n}\end{array}$ & $\begin{array}{l}\text { Std. } \\
\text { Dev. }\end{array}$ & $\begin{array}{l}\text { Medi } \\
\text { an }\end{array}$ & & \\
\hline Percentage of female CEOs & 0.100 & 0.305 & 0.0 & $\begin{array}{r}0.06 \\
4\end{array}$ & 0.245 & 0.0 & $\begin{array}{r}1821.0 \\
00\end{array}$ & 0.484 \\
\hline Age of CEO§ & 3.900 & 1.248 & 4.0 & $\begin{array}{r}4.10 \\
0\end{array}$ & 1.007 & 4.0 & $\begin{array}{r}1761.0 \\
00\end{array}$ & 0.341 \\
\hline $\begin{array}{l}\text { Managerial experience of } \\
\text { CEOs in years\& }\end{array}$ & 3.000 & 1.238 & 3.0 & $\begin{array}{r}3.18 \\
0\end{array}$ & 1.348 & 3.0 & $\begin{array}{r}1819.0 \\
00\end{array}$ & 0.502 \\
\hline $\begin{array}{l}\text { Level of education of } \\
\text { CEOs\# }\end{array}$ & 4.030 & 1.608 & 4.0 & $\begin{array}{r}4.62 \\
0\end{array}$ & 1.321 & 4.0 & $\begin{array}{r}1508.5 \\
00\end{array}$ & 0.064 \\
\hline
\end{tabular}

Note:

$E=2$-tailed Mann-Whitney

U test

$\S=$ Scale: $1=-20 ; 2=21-30 ; 3=31-40 ; 4=41-50 ; 5=51-60 ; 6=61$ - years 
$\&=$ Scale: $1=-5 ; 2=6-10 ; 3=11-15 ; 4=16-20 ; 5=21$ - years of experience

\# = Scale: 1 = primary school, $2=$ high school, $3=$ lower vocational school degree, $4=$ higher vocational school degree, $5=$ lower university degree, $6=$ higher university degree

Table 4 presents descriptive statistics of the four variables for CEOs' personal characteristics. The table shows that the percentage of female CEOs is higher in crisis firms than in non-crisis firms, but the difference is not statistically significant. The managers in both groups do not differ significantly with respect to age and experience. However, the average education level of CEOs is higher in non-crisis firms than in crisis firms. This finding could indicate that having a CEO with a higher level of education might make a firm less vulnerable to crisis. In summary, there are some differences in CEOs' personal characteristics (especially education level) between the crisis and non-crisis firms that may affect the issues under investigation.

\section{Managerial-role emphasis and role ambiguity}

Table 5 presents descriptive statistics for the importance of Mintzberg's managerial roles in crisis and non-crisis firms. The importance of interpersonal roles is lower in crisis firms than in non-crisis firms except for tasks 5 and 6. The interpersonal tasks 1 through 4 describe managerial work associated with social or performance situations, usually with subordinates, while task 5 describes interaction with colleagues and task 6 describes the handling of mail. The findings support hypothesis H3a for tasks 1 through 4 but not for tasks 5 and 6 . This result can be explained by a typical symptom of CEOs' stress: social withdrawal associated with a tendency to maintain social support from colleagues (Weiss, 1983). Handling of mail requires no social interaction.

For informational role tasks, a statistically significant difference was found only for task 10; CEOs in crisis firms placed less importance on regularly holding discussions with their supervisor or board than CEOs in non-crisis firms did. Thus, this evidence does not support the rejection of null proposition $\mathrm{H3c}$, with the exception of task 10. The lower importance given to task 10 may be a consequence of crisis and stress. Because of financial distress and a fear of social or performance situations, CEOs may perceive discussions with the board to be less important under these circumstances. In objective terms, this kind of discussion is very important.

In addition, CEOs in the crisis group tended to place less importance on decisional role tasks than their counterparts in the non-crisis group. Thus, the evidence supports proposition H3b. However, a few statistically significant differences were found, but in tasks 13 and 16 only. Task 13 is associated with supervising design and implementation of organizational projects. Under circumstances of crisis, it is understandable that a CEO would pay less attention to design and implementation of projects. Task 16 refers to conducting strategy sessions when problems arise that threaten the organization. In the same way as for task 10, CEOs may regard strategy sessions as less important than their counterparts in non-crisis firms due to financial distress and a fear of social situations under these circumstances. 
Table 5. Importance of managerial roles in CEO work

\begin{tabular}{|c|c|c|c|c|c|c|c|c|}
\hline \multirow[b]{3}{*}{ Managerial role } & \multirow{2}{*}{\multicolumn{3}{|c|}{ Crisis firms }} & \multirow{2}{*}{\multicolumn{3}{|c|}{ Non-crisis firms }} & \multirow[b]{3}{*}{$\begin{array}{l}\text { F } \\
\text { Statisti } \\
\text { c\& }\end{array}$} & \multirow[b]{3}{*}{$\begin{array}{l}\text { p- } \\
\text { valu } \\
\text { e }\end{array}$} \\
\hline & & & & & & & & \\
\hline & Mean & $\begin{array}{l}\text { Std. } \\
\text { Dev. }\end{array}$ & Median & $\begin{array}{l}\text { Me } \\
\text { an }\end{array}$ & $\begin{array}{l}\text { Std. } \\
\text { Dev. }\end{array}$ & $\begin{array}{l}\text { Medi } \\
\text { an }\end{array}$ & & \\
\hline \multicolumn{9}{|l|}{ A. INTERPERSONAL ROLE VARIABLES } \\
\hline \multicolumn{9}{|l|}{ 1. FIGUREHEAD } \\
\hline $\begin{array}{l}\text { 1. Present employees with prizes or } \\
\text { certificates at ceremonies. }\end{array}$ & 2.87 & 1.41 & 3.00 & $\begin{array}{r}3.4 \\
6\end{array}$ & 1.36 & 4.00 & 4.810 & $\begin{array}{r}0.02 \\
9\end{array}$ \\
\hline $\begin{array}{l}\text { 2. Represent the organization in outside } \\
\text { bodies or at public functions. }\end{array}$ & 3.33 & 1.42 & 3.00 & $\begin{array}{r}4.1 \\
5\end{array}$ & 1.25 & 4.00 & 10.581 & $\begin{array}{r}0.00 \\
1\end{array}$ \\
\hline \multicolumn{9}{|l|}{ 2. LEADER } \\
\hline $\begin{array}{l}\text { 3. Conduct employment, disciplinary, or } \\
\text { appraisal interviews. }\end{array}$ & 3.27 & 1.20 & 3.00 & $\begin{array}{r}3.7 \\
7\end{array}$ & 1.23 & 4.00 & 4.323 & $\begin{array}{r}0.03 \\
9 \\
\end{array}$ \\
\hline $\begin{array}{lccc}4 . & \text { Hold regular } & \text { meetings } & \text { with } \\
\text { subordinates. }\end{array}$ & 4.03 & 0.89 & 4.00 & $\begin{array}{r}4.5 \\
4\end{array}$ & 1.13 & 5.00 & 5.497 & $\begin{array}{r}0.02 \\
0\end{array}$ \\
\hline \multicolumn{9}{|l|}{ 3. LIAISON } \\
\hline $\begin{array}{l}\text { 5. Regularly hold discussions with } \\
\text { colleagues in other organizations. }\end{array}$ & 4.10 & 1.00 & 4.00 & $\begin{array}{r}4.0 \\
8\end{array}$ & 1.21 & 4.00 & 0.008 & $\begin{array}{r}0.92 \\
9 \\
\end{array}$ \\
\hline $\begin{array}{l}\text { 6. Acknowledge mail from } \\
\text { organizations. }\end{array}$ & 3.17 & 0.95 & 3.00 & $\begin{array}{r}3.1 \\
8\end{array}$ & 1.03 & 3.00 & 0.005 & $\begin{array}{r}0.94 \\
4 \\
\end{array}$ \\
\hline \multicolumn{9}{|l|}{ B. INFORMATIONAL ROLE VARIABLES } \\
\hline 4. MONITOR & & & & & & & & \\
\hline $\begin{array}{l}\text { 7. Regularly make tours of inspection } \\
\text { around workplace. }\end{array}$ & 3.37 & 1.43 & 3.50 & $\begin{array}{r}3.2 \\
4 \\
\end{array}$ & 1.45 & 3.00 & 0.192 & $\begin{array}{r}0.66 \\
1 \\
\end{array}$ \\
\hline $\begin{array}{l}\text { 8. Meet fellow managers to discuss mutual } \\
\text { problems. }\end{array}$ & 4.20 & 1.40 & 5.00 & $\begin{array}{r}4.0 \\
4\end{array}$ & 1.50 & 4.00 & 0.290 & $\begin{array}{r}0.59 \\
1\end{array}$ \\
\hline \multicolumn{9}{|l|}{ 5. DISSEMINATOR } \\
\hline $\begin{array}{l}\text { 9. Transmit information to subordinates or } \\
\text { other appropriate persons in organization. }\end{array}$ & 3.77 & 1.17 & 4.00 & $\begin{array}{r}3.9 \\
4\end{array}$ & 1.28 & 4.00 & 0.492 & $\begin{array}{r}0.48 \\
4\end{array}$ \\
\hline $\begin{array}{l}\text { 10. Hold review sessions regarding } \\
\text { information with subordinates or other } \\
\text { appropriate persons. }\end{array}$ & 3.77 & 1.33 & 4.00 & $\begin{array}{r}4.0 \\
4 \\
\end{array}$ & 1.14 & 4.00 & 1.386 & $\begin{array}{r}0.24 \\
0 \\
\end{array}$ \\
\hline \multicolumn{9}{|l|}{ 6. SPOKESMAN } \\
\hline $\begin{array}{l}\text { 11. Regularly hold discussions with own } \\
\text { supervisor or Board. }\end{array}$ & 3.23 & 1.46 & 3.00 & $\begin{array}{r}3.8 \\
9\end{array}$ & 1.61 & 4.00 & 4.468 & $\begin{array}{r}0.03 \\
6 \\
\end{array}$ \\
\hline $\begin{array}{l}\text { 12. Act as expert or spokesman for section } \\
\text { or organization. }\end{array}$ & 3.87 & 1.11 & 4.00 & $\begin{array}{r}4.1 \\
8\end{array}$ & 1.44 & 4.00 & 1.281 & $\begin{array}{r}0.25 \\
9\end{array}$ \\
\hline \multicolumn{9}{|l|}{ C. DECISIONAL ROLE VARIABLES } \\
\hline \multicolumn{9}{|l|}{ 7. ENTREPRENEUR } \\
\hline $\begin{array}{l}\text { 13. Supervise design and implementation } \\
\text { of organizational projects. }\end{array}$ & 4.14 & 1.27 & 4.00 & $\begin{array}{r}4.6 \\
4 \\
\end{array}$ & 1.24 & 5.00 & 4.059 & $\begin{array}{r}0.04 \\
5 \\
\end{array}$ \\
\hline $\begin{array}{l}\text { 14. Seek opportunities in environment to } \\
\text { initiate improvements in organization. }\end{array}$ & 4.55 & 1.30 & 5.00 & $\begin{array}{r}4.8 \\
6 \\
\end{array}$ & 1.17 & 5.00 & 1.680 & $\begin{array}{r}0.19 \\
6 \\
\end{array}$ \\
\hline \multicolumn{9}{|l|}{ 8. DISTURBANCE HANDLER } \\
\hline $\begin{array}{l}\text { 15. Adjudicate sudden conflicts (over many } \\
\text { issues) among subordinates. }\end{array}$ & 3.70 & 1.32 & 4.00 & $\begin{array}{r}3.9 \\
8\end{array}$ & 1.39 & 4.00 & 1.091 & $\begin{array}{r}0.29 \\
7\end{array}$ \\
\hline $\begin{array}{l}\text { 16. Hold strategy sessions when problems } \\
\text { arise that threaten section or organization. }\end{array}$ & 3.70 & 1.49 & 4.00 & $\begin{array}{r}4.2 \\
9 \\
\end{array}$ & 1.34 & 4.00 & 4.858 & $\begin{array}{r}0.02 \\
9 \\
\end{array}$ \\
\hline \multicolumn{9}{|l|}{ 9. RESOURCE ALLOCATOR } \\
\hline $\begin{array}{l}\text { 17. Set program and/or budget for section } \\
\text { or organization and review regularly. }\end{array}$ & 4.07 & 1.46 & 4.00 & $\begin{array}{r}4.2 \\
5\end{array}$ & 1.36 & 4.00 & 0.479 & $\begin{array}{r}0.49 \\
0 \\
\end{array}$ \\
\hline $\begin{array}{l}\text { 18. Schedule work program and review } \\
\text { and change as needed. }\end{array}$ & 3.83 & 1.32 & 4.00 & $\begin{array}{r}4.1 \\
7 \\
\end{array}$ & 1.32 & 4.00 & 1.702 & $\begin{array}{r}0.19 \\
3 \\
\end{array}$ \\
\hline
\end{tabular}




\begin{tabular}{|c|c|c|c|c|c|c|c|c|}
\hline 10. NEGOTIATOR & & & & & & & & \\
\hline $\begin{array}{l}\text { 19. Represent section or organization at } \\
\text { negotiations with outside groups such as } \\
\text { unions or suppliers. }\end{array}$ & 3.50 & 1.17 & 3.50 & $\begin{array}{r}3.8 \\
3 \\
\end{array}$ & 1.53 & 4.00 & 1.300 & $\begin{array}{r}0.25 \\
5 \\
\end{array}$ \\
\hline $\begin{array}{l}\text { 20. Negotiate changes in contracts or } \\
\text { commitments with outsiders. }\end{array}$ & 3.97 & 1.27 & 4.00 & $\begin{array}{r}4.3 \\
7\end{array}$ & 1.37 & 4.00 & 2.326 & $\begin{array}{r}0.12 \\
9 \\
\end{array}$ \\
\hline
\end{tabular}

Note:

7-point Likert scale anchored with not important at all (1)

and extremely important (7)

Table 6 presents the average importance of tasks assigned by CEOs to different Mintzberg work-role categories. For interpersonal, decisional, and all role tasks together, the importance is statistically significantly lower in crisis firms than in non-crisis firms. However, the difference in importance of the informational role tasks between the groups is not significant. The influence of crisis on the importance of the three role categories was also analyzed by partial correlations between the crisis-group dummy and the importance variables. These correlations were controlled for significant contextual and personal variables (size, focusstrategy dummy, defender-strategy dummy, authority centralization, level of education, and PEU). These partial correlations are presented in the first part of Appendix 2 (model 2). The correlations are consistent with the results obtained from a comparison of the groups. However, controlling for PEU, the partial correlation between the group dummy and the importance of decisional tasks is diminished (model 3). In summary, it is apparent that a crisis tends to reduce the importance of managerial roles, confirming hypothesis H1. More accurately, a crisis situation tends to reduce the importance of interpersonal and decisional roles but not the importance of informational roles. These findings respectively support hypotheses H3a, H3b, and H3c.

Table 6. Average importance of work-role categories perceived by CEO (average importance of the roles in each category)

\begin{tabular}{|c|c|c|c|c|c|c|c|c|}
\hline \multirow[b]{3}{*}{ Role task impc } & \multirow{2}{*}{\multicolumn{3}{|c|}{ Crisis firms }} & \multirow{2}{*}{\multicolumn{3}{|c|}{ Non-crisis firms }} & \multirow[b]{3}{*}{$\begin{array}{l}\text { F } \\
\text { statistic }\end{array}$} & \multirow[b]{3}{*}{$\begin{array}{l}\text { p- } \\
\text { value\& }\end{array}$} \\
\hline & & & & & & & & \\
\hline & $\begin{array}{l}\text { Mea } \\
\mathrm{n}\end{array}$ & $\begin{array}{l}\text { Std. } \\
\text { Dev. }\end{array}$ & $\begin{array}{l}\text { Media } \\
\mathrm{n}\end{array}$ & $\begin{array}{l}\text { Mea } \\
\mathrm{n}\end{array}$ & $\begin{array}{l}\text { Std. } \\
\text { Dev. }\end{array}$ & $\begin{array}{l}\text { Media } \\
\text { n }\end{array}$ & & \\
\hline $\begin{array}{l}\text { Interpersonal managerial work-role } \\
\text { tasks }\end{array}$ & 3.51 & 0.83 & 3.58 & 3.87 & 0.77 & 3.83 & 6.483 & 0.012 \\
\hline $\begin{array}{l}\text { Informational managerial work-role } \\
\text { tasks }\end{array}$ & 3.68 & 0.94 & 3.92 & 3.90 & 0.91 & 4.00 & 1.406 & 0.238 \\
\hline $\begin{array}{l}\text { Decisional managerial work-role } \\
\text { tasks }\end{array}$ & 3.97 & 0.88 & 4.13 & 4.35 & 0.89 & 4.38 & 4.308 & 0.040 \\
\hline All managerial work-role tasks & 3.74 & 0.78 & 3.95 & 4.07 & 0.76 & 4.05 & 4.160 & 0.043 \\
\hline
\end{tabular}

Note:

7-point Likert scale anchored with not important at all (1) and extremely important (7)

$\&=$ two-tailed $p$-value for F-test

Table 7 presents the average importance of tasks among the five most important tasks, a measure that reflects role ambiguity among the CEOs surveyed. For each priority category, the average importance is lower for CEOs in crisis firms than for those in non-crisis firms. The differences are highly statistically significant for each priority category. The second part of Appendix 2 shows partial correlations for the relationship between the average importance of the top-three and top-five most important tasks and the crisis-group dummy, controlling for the significant contextual and personal variables (model 2). The partial correlations are negative and highly statistically significant, leading to the same conclusion reached when 
comparing the groups. Thus, evidence indicates that CEOs' role ambiguity is lower in crisis firms than in non-crisis firms, which supports hypothesis $\mathrm{H} 2$.

Table 7. Importance of work / role tasks most emphasized by CEOs (average importance of the tasks by priority category).

\begin{tabular}{|c|c|c|c|c|c|c|c|c|}
\hline \multirow[b]{3}{*}{ Role } & \multirow{2}{*}{\multicolumn{3}{|c|}{ Crisis firms }} & \multirow{2}{*}{\multicolumn{3}{|c|}{ Non-crisis firms }} & \multirow[b]{3}{*}{\begin{tabular}{|l} 
F \\
statisti \\
c
\end{tabular}} & \multirow[b]{3}{*}{ p- } \\
\hline & & & & & & & & \\
\hline & $\begin{array}{l}\text { Mea } \\
n\end{array}$ & $\begin{array}{l}\text { Std. } \\
\text { Dev. }\end{array}$ & $\begin{array}{l}\text { Medi } \\
\text { an }\end{array}$ & $\begin{array}{l}\text { Mea } \\
n\end{array}$ & $\begin{array}{l}\text { Std. } \\
\text { Dev. }\end{array}$ & $\begin{array}{l}\text { Medi } \\
\text { an }\end{array}$ & & \\
\hline $\begin{array}{l}\text { Importance of most important task (first } \\
\text { in priority) }\end{array}$ & 5.47 & 0.78 & 5.00 & 5.87 & 0.74 & 6.00 & 7.120 & 0.008 \\
\hline $\begin{array}{l}\text { Average importance of } 1-2 \text { most } \\
\text { important tasks }\end{array}$ & 5.30 & 0.74 & 5.00 & 5.72 & 0.69 & 6.00 & 8.765 & 0.004 \\
\hline $\begin{array}{l}\begin{array}{l}\text { Average importance of } 1-3 \\
\text { important tasks }\end{array} \\
\end{array}$ & 5.19 & 0.70 & 5.00 & 5.60 & 0.68 & 5.67 & 8.691 & 0.004 \\
\hline \begin{tabular}{|llll} 
Average importance of $1-4$ & most \\
important tasks
\end{tabular} & 5.07 & 0.69 & 5.00 & 5.49 & 0.68 & 5.50 & 9.278 & 0.003 \\
\hline $\begin{array}{l}\text { Average importance of } 1-5 \text { most } \\
\text { important tasks }\end{array}$ & 4.95 & 0.70 & 5.00 & 5.38 & 0.69 & 5.20 & 9.676 & 0.002 \\
\hline Average importance of all 20 tasks & 3.74 & 0.78 & 3.95 & 4.07 & 0.76 & 4.05 & 4.160 & 0.043 \\
\hline
\end{tabular}

Note:

7-point Likert scale anchored with not important at all (1) and extremely important (7)

$\&=$ two-tailed $p$-value for F-test

\section{Time horizon and place of work}

Hypotheses $\mathrm{H} 4$ and $\mathrm{H} 5$ are associated with the time horizon of CEOs' managerial tasks and the physical place in which they work, respectively. Table 8 reports how much time CEOs in crisis and non-crisis firms spend on tasks with different time horizons. It shows that CEOs in crisis firms tend to spend more time on daily tasks with a horizon of less than one month and less time on tasks with a longer time horizon. The difference between the groups is statistically significant for tasks with time horizons of one to three years (tactical tasks) and over three years (strategic tasks). This evidence supports hypothesis H4 regarding CEOs' usage of time in crisis firms. Appendix 3 (in the first part) shows partial correlations for the association between time spent on tasks with different time horizons and the crisis-group dummy, controlled for the set of significant contextual and personal variables. When these variables are controlled for, the correlations are not statistically significant (model 2). However, if this set of variables, excluding PEU (model 3), is controlled for, correlations are similar to the uncontrolled correlations (model 1), indicating that PEU is associated with crisis, which causes CEOs to spend less time on longer-term tasks. Because PEU belongs to the domain of crisis, this kind of response is typical of a CEO in a crisis firm.

Hypothesis H5 deals with the location of work. Table 9 shows how much time CEOs in crisis and non-crisis firms spend working in different physical locations. The figure averages show that CEOs in crisis firms spend less time in their offices and more time elsewhere inside and outside their firm. The difference between crisis and non-crisis firms regarding time spent in these locations is statistically significant, which supports H5. The second part of Appendix 3 reports partial correlations between the place-of-work variables and the crisis-group dummy, controlled for the significant contextual and personal variables. The level of controlled partial correlations (model 2) is slightly lower than for uncontrolled correlations (model 1). However, 
controlled partial correlations are statistically significant and parallel with H4. Thus, the available evidence supports hypothesis $\mathrm{H} 4$.

Table 8. Time spent on tasks by different time horizon

\begin{tabular}{|c|c|c|c|c|c|c|c|c|}
\hline & \multicolumn{3}{|c|}{ Crisis firms } & \multicolumn{3}{|c|}{ Non-crisis firms } & & \\
\hline Time horizon of task & $\begin{array}{l}\text { Mea } \\
\mathrm{n}\end{array}$ & $\begin{array}{l}\text { Std. } \\
\text { Dev. }\end{array}$ & $\begin{array}{l}\text { Med } \\
\text { ian }\end{array}$ & $\begin{array}{l}\text { Me } \\
\text { an }\end{array}$ & $\begin{array}{l}\text { Std. } \\
\text { Dev. }\end{array}$ & $\begin{array}{l}\text { Med } \\
\text { ian }\end{array}$ & $\begin{array}{l}\text { F } \\
\text { Statist } \\
\text { ic } \\
\end{array}$ & $\begin{array}{l}\text { - } \\
\text { valu } \\
\text { e } \\
\end{array}$ \\
\hline Less & 4.66 & 0.97 & 5.00 & $\begin{array}{r}4.4 \\
1 \\
\end{array}$ & 1.02 & 4.00 & 1.455 & $\begin{array}{r}0.22 \\
9 \\
\end{array}$ \\
\hline One-month to one-year time horizon & 4.34 & 1.08 & 4.00 & $\begin{array}{r}4.5 \\
8 \\
\end{array}$ & 0.84 & 5.00 & 1.815 & $\begin{array}{r}0.17 \\
9 \\
\end{array}$ \\
\hline One-year to three-year time horizon & 3.69 & 1.11 & 4.00 & $\begin{array}{r}4.1 \\
9 \\
\end{array}$ & 0.99 & 4.00 & 6.389 & $\begin{array}{r}0.01 \\
2 \\
\end{array}$ \\
\hline Over three-year time horizon & 3.28 & 1.22 & 3.00 & $\begin{array}{r}3.9 \\
4\end{array}$ & 1.27 & 4.00 & 7.001 & $\begin{array}{r}0.00 \\
9\end{array}$ \\
\hline
\end{tabular}

Note:

7-step Likert scale anchored with none (1)

and a very great deal (7)

Table 9. Time spent on tasks in different places

\begin{tabular}{|c|c|c|c|c|c|c|c|c|}
\hline & \multicolumn{3}{|c|}{ Crisis firms } & \multicolumn{3}{|c|}{ Non-crisis firms } & \multirow[b]{2}{*}{$\begin{array}{l}\text { F } \\
\text { Statist } \\
\text { ic }\end{array}$} & \multirow[b]{2}{*}{$\begin{array}{l}\text { p- } \\
\text { valu } \\
\text { e } \\
\end{array}$} \\
\hline Place of work & $\begin{array}{l}\text { Mea } \\
\mathrm{n}\end{array}$ & $\begin{array}{l}\text { Std. } \\
\text { Dev. }\end{array}$ & $\begin{array}{l}\text { Med } \\
\text { ian }\end{array}$ & $\begin{array}{l}\text { Me } \\
\text { an }\end{array}$ & $\begin{array}{l}\text { Std. } \\
\text { Dev. }\end{array}$ & $\begin{array}{l}\text { Med } \\
\text { ian }\end{array}$ & & \\
\hline CEO's own office & 3.73 & 1.20 & 4.00 & 4.38 & 1.30 & 5.00 & 6.669 & 0.010 \\
\hline Elsewh & 4.04 & 1.26 & 4.00 & 3.39 & 1.29 & 3.00 & 6.183 & .014 \\
\hline $\begin{array}{l}\text { Business t } \\
\text { firm }\end{array}$ & 3.76 & 1.27 & 4.00 & 3.52 & 1.09 & 3.00 & 1.103 & 0.295 \\
\hline $\begin{array}{l}\text { Home doing remote work for CEO's } \\
\text { firm }\end{array}$ & 3.10 & 1.24 & 3.00 & 3.06 & 1.25 & 3.00 & 0.025 & 0.874 \\
\hline Elsewhere outside CEO's firm & 3.34 & 1.50 & 3.00 & 2.86 & 1.26 & 3.00 & 3.532 & 0.062 \\
\hline
\end{tabular}

Note:

7-step Likert scale anchored with none (1)

and a very great deal (7)

\section{Importance and availability of information}

Hypotheses $\mathrm{H} 6$ and $\mathrm{H} 7$ are associated with the importance and availability of information to CEOs for their managerial work. The first panel of Table 10 represents the importance CEOs in crisis and non-crisis firms place on information from different sectors. In general, CEOs in crisis firms tend to place less importance on information than their counterparts in non-crisis firms, with the exception of competitor information. The most significant differences between the firm groups are the importance of the employee and internal process sectors of information. However, differences in information from the customer and financial sectors are also statistically significant. In both groups, CEOs regard customer information as the most important form. Thus, crisis firms also consider customer information the most important although it is external and deals with output (cf. D'Aveni \& MacMillan, 1990). CEOs in crisis firms also place a great deal of emphasis on financial, employee, and innovation and learning information (internal input information). 
The comparison of the importance of information in crisis and non-crisis firms supports H6 although it does not deal with information on internal processes. The first panel of Appendix 4 presents partial correlations between the importance of information from different sectors and the crisis-group dummy controlled for the set of control variables. This appendix shows that controlled partial correlations (model 2) are, for the most part, more similar than uncontrolled correlations (model 1), which partly supports prior conclusions above and H6. However, the controlled correlation between the importance of financial information and the crisis-group dummy is not statistically significant. This evidence indicates that CEOs in crisis firms place less importance on customer and employee information than their counterparts in non-crisis firms supporting H6. The findings do not support the same suggestion in terms of financial information. Statistical analyses (not reported here) show that the importance of financial information is negatively correlated with the focus-strategy dummy $(-0.146)$ and the defenderstrategy dummy (-0.161) used as control variables. Thus, the importance of financial information is associated more with strategy than with crisis.

Table 10. Importance and availability of information from different sectors

\begin{tabular}{|c|c|c|c|c|c|c|c|c|}
\hline \multirow[b]{2}{*}{ Information sector } & \multicolumn{3}{|c|}{ Crisis firms } & \multicolumn{3}{|c|}{ Non-crisis firms } & \\
\hline & $\begin{array}{l}\text { Mea } \\
\mathrm{n}\end{array}$ & $\begin{array}{l}\text { Std. } \\
\text { Dev. }\end{array}$ & $\begin{array}{l}\text { Media } \\
\mathrm{n}\end{array}$ & $\begin{array}{l}\text { Mea } \\
\mathrm{n}\end{array}$ & $\begin{array}{l}\text { Std. } \\
\text { Dev. }\end{array}$ & $\begin{array}{l}\text { Medi } \\
\text { an }\end{array}$ & $\begin{array}{l}\text { F } \\
\text { Statisti } \\
c\end{array}$ & $\begin{array}{l}\text { p- } \\
\text { valu } \\
\text { e }\end{array}$ \\
\hline \multicolumn{9}{|l|}{$\begin{array}{l}\text { 1. Importance of information if } \\
\text { available } \S\end{array}$} \\
\hline Financial sector & 5.43 & 1.01 & 5.50 & 5.78 & 0.94 & 6.00 & 3.493 & 0.063 \\
\hline Customer sector & 5.80 & 0.96 & 6.00 & 6.14 & 0.77 & 6.00 & 4.773 & 0.030 \\
\hline Supplier sector & 4.77 & 1.65 & 5.00 & 5.12 & 1.29 & 5.00 & 1.786 & 0.183 \\
\hline Competitor sector & 4.67 & 1.24 & 5.00 & 4.62 & 1.24 & 5.00 & 0.032 & 0.858 \\
\hline Employee sector & 5.33 & 1.30 & 5.50 & 5.87 & 0.90 & 6.00 & 8.172 & 0.005 \\
\hline Internal processes sector & 4.90 & 1.52 & 5.00 & 5.48 & 0.97 & 6.00 & 7.693 & 0.006 \\
\hline Innovation and learning sector & 5.40 & 1.25 & 6.00 & 5.64 & 1.06 & 6.00 & 1.298 & 0.256 \\
\hline \multicolumn{9}{|l|}{ 2. Availability of information\& } \\
\hline Financial sector & 5.03 & 1.00 & 5.00 & 5.72 & 0.92 & 6.00 & 13.886 & 0.000 \\
\hline Customer sector & 4.31 & 1.04 & 5.00 & 4.83 & 0.84 & 5.00 & 8.975 & 0.003 \\
\hline Supplier sector & 4.10 & 1.11 & 4.00 & 4.51 & 1.11 & 5.00 & 3.302 & 0.071 \\
\hline Competitor sector & 3.79 & 1.08 & 4.00 & 3.98 & 1.12 & 4.00 & 0.690 & 0.407 \\
\hline Employee sector & 4.40 & 1.25 & 4.50 & 5.06 & 0.83 & 5.00 & 13.815 & 0.000 \\
\hline Internal processes sector & 4.40 & 1.10 & 4.50 & 4.79 & 1.02 & 5.00 & 3.636 & 0.058 \\
\hline Innovation and learning sector & 3.93 & 1.14 & 4.00 & 4.41 & 1.03 & 4.00 & 5.464 & 0.020 \\
\hline
\end{tabular}

Note:

$\S=7$-point Likert scale anchored with not important at all (1)

and extremely important (7)

$\&=7$-point Likert scale anchored with not available at all (1)

and extremely available

Hypothesis $\mathrm{H7}$ is related to the availability of information from different sectors. The second part of Table 9 reports the availability of information to CEOs in crisis and non-crisis firms. For CEOs in crisis firms, the level of information availability is significantly lower than for CEOs in non-crisis firms, with the exception of competitor information (with the lowest level of availability). The differences are most significant for information from the financial, employee, and customer perspectives, which supports H7. The second panel of Appendix 4 presents partial correlations for the availability of information from different sectors and the crisis- 
group dummy controlled for the set of control variables. These results (model 2) show that only the partial correlations for financial, customer, and employee information are statistically significant. The results also show that the level of partial correlations is significantly higher when PEU is excluded from the set of control variables (model 3). Thus, PEU is an important variable affecting the availability of information as perceived by CEOs. In summary, there is strong evidence supporting H7.

\section{Logistic regression}

Empirical evidence supports the research hypotheses, which indicates there are significant differences in CEOs' behavior in crisis and non-crisis firms. However, this univariate evidence does not tell us how well these differences as a whole discriminate between crisis and noncrisis firms. Table 11 presents the results of a multivariate stepwise logistic regression analysis where all the original variables under investigation are used as predictors. The resulting logistic regression model is reported in Panel 2. The panel shows that the final model includes five predictors indicating that the likelihood of belonging to the group of crisis firms is higher, the lower a CEO assesses the importance of holding strategy sessions when problems arise that threaten the section or organization, the less time a CEO spends on strategic tasks, the more time a CEO spends elsewhere than in the firm's offices, and the lower the availability of employee and financial information. The goodness of the model fit is quite high (Panel 1), and the logistic model correctly classified $76.4 \%$ of the firms (Panel 3). Figure 1 shows the ROC curve for the model. The accuracy ratio (AR) for the model is 0.662 , indicating above average accuracy.

Table 11. Estimation results of logistic regression analysis

Panel 1. Model Summary

\begin{tabular}{|l|r|}
\hline -2 Log Likelihood & 104.118 \\
\hline Omnibus test on model coefficients. Chi-Square & 44.516 \\
\hline p-value & 0.000 \\
\hline Cox \& Snell R Square & 0.227 \\
\hline Nagelkerke R Square & 0.358 \\
\hline Hosmer and Lemeshow test statistic & 12.132 \\
\hline p-value & 0.145 \\
\hline
\end{tabular}

Panel 2. Estimated logistic regression model

\begin{tabular}{|c|c|c|c|c|c|}
\hline Variables in the Equation & $\begin{array}{l}\text { B } \\
\text { coefficient }\end{array}$ & $\begin{array}{l}\text { Stand. } \\
\text { Error }\end{array}$ & $\begin{array}{l}\text { Wald } \\
\text { statistic }\end{array}$ & $\begin{array}{l}\mathrm{p}- \\
\text { value }\end{array}$ & $\operatorname{Exp}(B)$ \\
\hline $\begin{array}{l}\text { Task } 16 . \text { Hold strategy sessions when problems } \\
\text { arise that threaten section or organization }\end{array}$ & -0.340 & 0.199 & 2.905 & 0.088 & 0.712 \\
\hline Time spent on tasks for over three years & -0.341 & 0.213 & 2.569 & 0.109 & 0.711 \\
\hline Working elsewhere inside the CEO's firm & 0.551 & 0.203 & 7.392 & 0.007 & 1.736 \\
\hline Availability of employee information & -0.580 & 0.259 & 5.029 & 0.025 & 0.560 \\
\hline Availability of financial information & -0.752 & 0.257 & 8.562 & 0.003 & 0.472 \\
\hline Constant & 5.986 & 1.921 & 9.709 & 0.002 & 397.623 \\
\hline
\end{tabular}

Panel 3. Classification based on predicted probability (cut-off value $=$ $0.19)$ 


\begin{tabular}{|l|l|r|}
\hline \multicolumn{3}{|c|}{ Predicted class: } \\
\hline $\begin{array}{l}\text { Original } \\
\text { class: }\end{array}$ & $\begin{array}{l}\text { Non-crisis } \\
\text { firms }\end{array}$ & Crisis firms \\
\hline $\begin{array}{l}\text { Non-crisis } \\
\text { firms }\end{array}$ & $75.89 \%$ & $24.11 \%$ \\
\hline Crisis firms & $21.43 \%$ & $78.57 \%$ \\
\hline Overall & & $76.43 \%$ \\
\hline
\end{tabular}

Appendix 5 presents a similar logistic regression model including PEU as an additional predictor. The goodness of the model fit is then slightly improved (Panel 1), but the classification accuracy is almost identical (Panel 3). The coefficient of PEU is positive and highly statistically significant (Panel 2). The coefficients of other predictors and their significance are comparable with those in the original model, with one exception: the variable measuring how much time a CEO spends on strategic tasks is no longer significant. Thus, PEU does little to increase the performance of the logistic regression model and merely substitutes the information contained by this variable. This result was expected given the univariate results.

\section{Discussion}

\section{DISCUSSION AND SUMMARY}

This study suggests that crisis situations have several consequences for the management of firms that must adapt to external threats that radically alter the business environment and financial situation. In small and medium enterprises (SMEs), CEOs play central roles: they have a great deal of power to make and implement decisions but also have many responsibilities toward stakeholders such as employees and financiers. Generally, CEOs are also owners of their firms and thus financial risk can affect their personal property. Accordingly, the threat of a crisis puts CEOs in a very difficult situation as they are surrounded by internal and external tensions, causing them to become increasingly stressed during the process of decline toward crisis (cf. Staw, Sandelands \& Dutton, 1981). In this study, it is expected that this adaptation causes CEOs to adjust their emphasis on managerial work roles, leading to differences between crisis and non-crisis firms in general (H1). It is further suggested that this transitory situation makes CEOs uncertain about their role as chief executive. This kind of uncertainty is expected to result in increased role ambiguity (H2), which can have many negative personal consequences for CEOs (Marginson, 2006).

These hypotheses are strongly supported by empirical evidence since CEOs in crisis firms generally place less emphasis on Mintzberg's role tasks than their counterparts in non-crisis firms. In addition, they place less emphasis on the tasks at the top of their priority list, reflecting greater role ambiguity. While many believe these differences are due to differences in contextual environment or personal characteristics, the findings remain valid when controlling for a large set of contextual and personal variables. The findings were also validated by the inclusion in the survey of a control question about how sure a CEO is about his or her philosophy of leading (results not reported here): CEOs in crisis firms were highly statistically significantly less sure about their philosophy than their counterparts in non-crisis firms. Control questions also revealed that CEOs in crisis firms work more hours per week and are less satisfied with the distribution of working hours on different tasks. However, these questions did not directly investigate how CEOs in crisis and non-crisis firms differ with respect to personality traits and levels of stress. These aspects would be interesting to investigate in further studies. 
It is also interesting to examine how CEOs in crisis and non-crisis firms emphasize Mintzberg's (1973) various role categories. Interpersonal roles are concerned with interpersonal relationships (managing through people), informational roles with information aspects (managing through information), and decisional roles with decision making (managing through action). This study suggests that CEOs suffer from typical symptoms of stress such as fear of social situations with subordinates and indecisiveness (Staw, Sandelands \& Dutton, 1981; Weiss, 1983). It is suggested that these symptoms lead CEOs in crisis firms to place less emphasis on interpersonal and decisional roles (propositions H3a and H3b). However, it is difficult to specify how a crisis will affect the emphasis on informational roles because it may lead to information overload, restriction of information processing, or even freezing on wellknown practices (Staw, Sandelands \& Dutton, 1981). Therefore, it is suggested as a null hypothesis that CEOs in crisis and non-crisis firms place equal emphasis on informational roles (proposition H3c).

Evidence also supports these propositions when controlling for a set of contextual and personal variables. The importance of interpersonal tasks is lower for CEOs in crisis firms when these tasks deal with social or performance situations with subordinates. However, when the tasks deal with interaction with colleagues, the emphasis placed on them does not differ between CEOs in crisis and non-crisis firms. This may be a consequence of the need to maintain social support from colleagues (Weiss, 1983). In general, CEOs in crisis firms assign less importance to decisional role tasks. However, significant differences are found only when the tasks deal with either supervising organizational projects or holding strategy sessions with the board. Under crisis circumstances, organizational projects can be frozen and fear of performance situations may cause CEOs to avoid sessions with the board. Only one informational role task is significantly different between the firm groups: CEOs in crisis firms place less emphasis on regular discussions with their supervisor or board. This is obviously a consequence of a fear of social situations. The assumption about fear of social situations was controlled for by a survey question (not reported here) about how important CEOs consider telling subordinates they have performed good work. CEOs in crisis firms consider this less important than their counterparts in non-crisis firms to a high degree of statistical significance. An additional control question (not reported here) showed that CEOs in crisis firms spend less time in meetings with other people than their counterparts in non-crisis firms.

It is expected that crisis alters the time horizon of managerial tasks accomplished by CEOs. In the final stages of organizational decline, limits on CEOs' time and attention guarantee that not all issues will be attended to equally (Dutton, 1986). It is suggested (H4) that CEOs' prioritization of tasks changes under circumstances of crisis from long-term time-horizon tasks toward short-term time-horizon tasks (Smart \& Vertinsky, 1977; D'Aveni, 1989; D'Aveni \& MacMillan, 1990). Evidence provides obvious support for this hypothesis. In crisis firms, CEOs spend less time on managerial tasks with a horizon of one to three years (tactical tasks) and over three years (strategic tasks). However, control analysis indicates that this difference is due to the higher PEU perceived by CEOs in crisis firms. Accordingly, high PEU makes longterm tasks less attractive to CEOs, but also makes long-term planning more difficult. The survey also investigated this issue with a control question (not reported here) that asked how much time CEOs spend on planning tasks in general. The results show that CEOs in crisis firms spend less time on planning tasks than their counterparts in non-crisis firms. However, CEOs in crisis and non-crisis firms spend equal time on the control tasks. Due to high PEU, one would expect them to spend more time on such tasks (Staw, Sandelands \& Dutton, 1981).

It is also expected that crisis influences the locations where CEOs conduct their work. In the final stages of decline, CEOs may be strongly oriented toward results, which means they are 
intensely motivated to spend less time in the office (H5). Evidence provides strong support for this hypothesis, even when controlling for a set of contextual and personal variables. Evidence shows that CEOs in crisis firms tend to spend less time in the office and more time elsewhere, whether inside or outside the firm. This finding is also supported by the relatively high importance CEOs place on the tasks of holding discussions with colleagues in other organizations and meeting fellow managers to discuss mutual problems, behavior related to searching for social support from colleagues. The tendency to work outside the office is supported by the highest importance given to the task of seeking opportunities to initiate improvements in an organization. This task is also strongly acknowledged by CEOs in noncrisis firms. This finding is expected since non-crisis firms also suffered from effects of the Great Recession.

Information is the first link in the chain of perceptions and actions that permit an organization to adapt (Daft, Sormunen \& Parks, 1988). The threat-response model argues that CEOs' stress changes their information-processing patterns and generates increased search behavior, which can result in information overload (Staw, Sandelands \& Dutton, 1981; D'Aveni \& MacMillan, 1990). This overload can cause CEOs to restrict information sectors and turn their attention to simplistic efficiency concerns (D'Aveni \& MacMillan, 1990). However, it has been suggested that SMEs in crisis suffer from the lack of apposite information rather than information overload (Lybaert, 1998). It is suggested that CEOs in crisis firms place less importance on critical success factors (financial, customer, and employee information) than their counterparts in non-crisis firms (H6). Further, it is suggested that the availability of such information is lower for CEOs in crisis firms (H7).

Evidence supports H6 in so far as CEOs in crisis firms place less importance on financial, customer, and employee information than CEOs in non-crisis firms. However, the importance of financial information is undermined by the strategy control variables. CEOs in firms using a generic focus strategy or a defender market strategy consider financial information less important, irrespective of the degree of crisis. There is also evidence supporting H7. The availability of information to CEOs in crisis firms is generally lower than for their counterparts in non-crisis firms. The most significant differences are found in financial, customer, and employee information, which confirms H7. However, it was also found that PEU is an important control variable: when the results are controlled for PEU, the association between crisis and the availability of information is weaker. This result is in agreement with contingency research on the importance of PEU (Chenhall, 2003). The availability of information was also verified by the inclusion of two control questions (not reported here) in the survey. CEOs in crisis firms were found to be significantly less satisfied with the information available to them than their counterparts in non-crisis firms. In addition, CEOs in crisis firms were found to be significantly less aware of the latest issues affecting their organization than CEOs in non-crisis firms.

\section{Conclusions}

In summary, the results indicate that crisis has a strong impact on CEOs' behavior with respect to the importance of managerial work and different sectors of information. These findings show that CEOs in crisis firms facing difficult financial circumstances tend to exhibit less role ambiguity and greater avoidance of interpersonal and decisional roles than their counterparts in non-crisis firms. They place less emphasis on information from different sectors and suffer more from lack of information, spending less time on planning and long-term tasks in general. They also spend more time outside their offices. These variables are also useful in identifying crisis firms. If these variables are concurrently included in multivariate logistic regression analysis, it is possible to classify firms in crisis and non-crisis groups with considerable 
accuracy. Therefore, these variables together form an important set for characterizing the behavioral differences between CEOs in crisis and non-crisis firms. Particularly, time spent outside the office and the perceived availability of financial and employee information play important roles in discriminating between the groups.

The present study contributes to theory and practice in many ways, particularly in showing how CEOs behave when threatened with a sudden and unexpected crisis. These findings can help managers and researchers better understand this behavior and to learn and develop methods to diminish unfavorable behavior to reduce, or even avoid, the impacts of a crisis. It is expected that these findings are relatively general and could be generalized for CEOs outside Finland. Finnish leadership is often described by the concept Management by Damn (Lämsä, 2010). This means that Finnish leaders are strong and authoritative, ultimately bearing the responsibility and ability to make large decisions alone and emphasizing their role as leaders. In Finnish organizations, it is important that the CEO is present and available because employees are accustomed to the leader always being accessible when needed. Finnish managers appreciate performance, are often impatient and honest, do not favor small talk, and are not afraid to say negative things (Lämsä, 2010). It is interesting that solving problems and handling chaotic circumstances are normal for Finns. A task will often begin although exact plans have not yet been fully finalized. These features may be unique to Finnish CEOs so it is possible that these features affect the way Finnish CEOs behave when threatened with a sudden crisis. However, it is expected that the differences in behavior between CEOs in crisis firms and those in non-crisis firms are largely generalizable to other cultures outside Finland.

The present study has several limitations, which can serve as suggestions for further research on crisis firms. This study is based on survey data and suffers from the standard weak points of such an approach (Van der Stede, Young \& Chen, 2005). In further studies, different methodologies should also be applied. Particularly, time-series analysis would be useful to verify the suggested causal relationships (cf. D'Aveni \& MacMillan, 1990). The survey was completed only by Finnish CEOs, who may have special characteristics such as a hard leadership style. Therefore, studies focusing on CEOs from other countries would be able to assess whether the findings can truly be generalized. In this study, a direct measure of role ambiguity or role clarity was not available (Marginson, 2006). The status of crisis was identified on the basis of CEOs' assessments of their firms' financial performance in relation to competitors. More accurate measures of role ambiguity and crisis should be applied in further studies. The hypotheses of this study are associated with the stress-related behavior of CEOs in crisis firms. However, the level of stress was not directly measured in any way. Finally, it would be interesting to measure CEOs' personalities in further research. It is expected that symptoms of stress are largely associated with different personality traits.

\section{ACKNOWLEDGMENTS}

This study was financially supported by OP-Pohjola Group Research Foundation (Kyösti Haataja Foundation), and this is gratefully acknowledged.

\section{References}

Argenti, J. (1976). Corporate Collapse: The Causes and Symptoms, McGraw-Hill: Maidenhead, UK.

Carlson, S. (1951). Executive Behaviour. Stockholm: Strömbergs.

Carroll, S.J. \& Gillen, D.J. (1984). The classical management functions: are they really outdated? Academy of Management Proceedings, 44: 132-136. 
Chenhall, R.H. (2003). Management control system design within its organizational context: findings from contingency-based research and directions for the future. Accounting, Organizations and Society, 28(2-3): 127168.

Chenhall, R.H. (2005). Integrative strategic performance measurement systems, strategic alignment of manufacturing, learning and strategic outcomes: an exploratory study. Accounting, Organizations and Society, 30(5): 395-422.

D'Aveni, R.A. (1989). The Aftermath of Organization Decline: A longitudinal study of strategic and managerial characteristics of declining Firms. Academy of Management Journal, 32(3): 577-605.

D'Aveni, R.A. \& MacMillan, I. (1990). Crisis and the content of managerial communications: a study of the focus of attention of top managers in surviving and failing firms. Administrative Science Quarterly, 35: 634-657.

Daft, R.L., Sormunen, J. \& Parks, D. (1988). Chief executive scanning, environmental characteristics, and company performance: An empirical study. Strategic Management Journal, 9: 123-139.

Drucker, P.F. (2005). The American CEO, Wall Street Journal, December 27.

Dutton, J. E. (1986). The processing of crisis and non-crisis strategic issues. Journal of Management Studies, 23: 501-517.

Fox, P. (1992). Exploring managers' jobs. Management Decision, 30(6): 52-63.

Gottschalk, P. (2002). The Chief Information Officer: a study of managerial roles in Norway, Proceedings of the 35th Hawaii International Conference on System Sciences. Hawaii.

Greenhalgh, L., Lawrence, A.T. \& Sutton, R.I. (1988) Determinants of workforce reduction strategies in declining organizations. Academy of Management Review, 13: 241-254.

Grover, V., Jeong S., Kettinger, W. \& Lee, C. (1993). The Chief Information Officer: a study of managerial roles. Journal of Management Information Systems, 10(2): 107 - 130.

Hall, D.T. \& Mansfield, R. (1971). Organizational and individual response to external stress. Administrative Science Quarterly, 16: 533-547.

Hall, M. (2008). The effect of comprehensive performance measurement systems on role clarity, psychological empowerment and managerial performance. Accounting, Organizations and Society, 33: 141-163.

Hall, M. (2010). Accounting information and managerial work. Accounting, Organizations and Society, 35(3): 301315 .

Hambrick, C. \& D'Aveni, R.A. (1988). Large corporate failures as downward spirals. Administrative Science Quarterly, 33: 1-23.

Hedberg, B.L., Nystrom P.C. \& Starbuck, W.H. (1976). Camping on seesaws: Prescriptions for a self-designing organization, Administrative Science Quarterly, 21: 41-65.

Hosmer, D.W. \& Lemeshow, S. (1989). Applied logistic regression. New York: Wiley.

Ittner, C.D. \& Larcker, D.F. (1998). Innovations in performance measurement: trends \& research implications. Journal of Management Accounting Research, 10: 205-238.

Ittner, C. D., Larcker, D.F. \& Meyer, M.W. (2003). Subjectivity and the Weighting of Performance Measures: Evidence from a Balanced Scorecard. The Accounting Review, 78(2): 725-758.

Kahn, R. L., Wolfe, D. M., Quinn, R. P., Snoek, J. D. \& Rosenthal, R. A. (1964). Organizational stress: Studies in role conflict and ambiguity. New York: Wiley.

Kaplan, R.S. \& Norton, D.P. (1992).The balanced scorecard - measures that drive performance. Harvard Business Review, 70(1/2): 71-79.

Kaufman, H. (1985). Time, Chance and Organizations: Natural Selection in a Perilous Environment. Chatham, NJ: Chatham House.

Kiesler, S. \& Sproull, L. (1982). Managerial response to changing environments: Perspectives on problem sensing from social cognition. Administrative Science Quarterly, 27: 548-570.

Kotter, J.P. (1982). The General Managers. New York: The Free Press. 
Kurke, L., \& Aldrich, H. (1983). Mintzberg was right! A replication and extension of the nature of managerial work. Management Science, 29(8): 975-984.

Levy, A. (1986). Second-order planned change: Definition and conceptualization. Organizational Dynamics, 15(1): 5-20.

Lybaert, N. (1998). The information Use in a SME: Its Importance and Some Elements of Influence. Small Business Economics, 10: 171-191.

Lämsä, T. (2010). Leadership styles and decision-making in Finnish and Swedish Organizations. Review of International Comparative Management, 11(1): 139-149.

Marginson, D. 2006. Information processing and management control: a note exploring the role played by information media in reducing role ambiguity. Management Accounting Research, 17(2): 187-197.

Mellahi, K. \& Wilkinson, A. (2004). Organizational failure: A critique of recent research and a proposed integrative framework. International Journal of Management Reviews, 5/6(1): 21-41.

Miles, R.E. and Snow, C.C. (1978). Organizational Strategy, Structure and Process. New York: McGraw-Hill.

Mintzberg, H. (1973). The Nature of Managerial Work. New York: Harper \& Row.

Mintzberg, H. (1975). The manager's job: folklore and fact. Harvard Business Review, 53(4): 49-61.

Mintzberg. H (1979). A new look at the Chief Executive's Job. Organizational Dynamics, 1(3): 21-30.

Mintzberg, H. (1989). Mintzberg on Management: Inside our Strange World of Organizations. New York: The Free Press, MacMillan, Inc.

Mintzberg, H. (1994). Rounding out the manager's job. Sloan Management Review, 35(2): 11-26.

Noordegraaf, M. \& Stewart, R. (2000). Managerial behavior research in private and public sectors: distinctiveness, disputes and directions. Journal of Management Studies, 37(3): 427-443.

Norreklit, H. (2000). The balance on the balanced scorecard: a critical analysis of some of its assumptions. Management Accounting Research, 11(1): 65-88.

Pfeffer, J. and Salancik, G.R. (1978). The External Control of Organizations: A Resource Dependence Perspective. New York: Harper \& Row.

Porter, M.E. (1980). Competitive Strategy: Techniques for Analyzing Industries and Competition. New York: Free Press.

Schendel, D., Patton, G.R. \& Riggs, J. (1976). Corporate turnaround strategies: A case of profit decline and recovery. Journal of General Management, 3(3): 3-12.

Smart, C. \& Vertinsky, M. (1977). Designs for crisis decision units. Administrative Science Quarterly, 22: 640-657.

Starbuck, W.H., Greve, A. \& Hedberg, B.L.T. (1978). Responding to crisis. Joumal of Business Administration, 9(2): 112-137.

Staw, B.M., Sandelands, L.E. \& Dutton, J.E. (1981). Threat-rigidity effects in organizational behavior: A multilevel analysis. Administrative Science Quarterly, 26: 501 -524.

Stewart, R. (1982). A model for understanding managerial jobs and behavior. The Academy of Management Review, 7(1): 7-13.

Stewart, R. (1988). Managers and their Jobs. London: MacMillan Press.

Tengblad, S. (2002).Time and space in managerial work. Scandinavian Journal of Management, 18(4): 543-565.

Tengblad, S. (2006). Is there a 'New Managerial Work'? A Comparison with Henry Mintzberg's Classic Study 30 Years Later. Journal of Management Studies, 43(7): 1437-1461.

Thompson, J.D. (1967). Organizations in Action. New York: McGraw-Hill.

Trahms, C.A., Ndofor, H.A. \& Sirmon, D.G. (2013). Organizational Decline and Turnaround A Review and Agenda for Future Research. Journal of Management, 39(5): 1277-1307 
Van der Stede, W.A., Young, S.M. \& Chen, C.X. (2005). Assessing the quality of evidence in empirical management accounting research: the case of survey studies. Accounting, Organizations and Society, 30 (7): 655-684.

Weiss, M. (1983). Effects of Work Stress and Social Support on Information Systems Managers, MIS Quarterly, $7(1): 29-43$.

Weitzel, W. \& Jonsson, E. (1989). Decline in Organisations: A Literature Integration and Extension. Administrative Science Quarterly, 34: 91-109.

Weitzel, W. \& Jonsson, E. (1991). Reversing the Downward Spiral: Lessons from W.T. Grant and Sears. The Academy of Management Executive, 5(3): 7-20.

\section{APPENDICES}

Appendix 1. Survey questions on the variables used in the study

\section{Managerial work role}

How important do you consider the following 20 tasks in your managerial work? (Use the following scale to assess importance: $1=$ no importance at all, $2=$ very little importance, $3=$ moderately little importance, $4=$ average importance, $5=$ moderate importance, $6=$ considerable importance, 7 = extreme importance)

(For the 20 managerial tasks, see Table 4)

\section{Time horizon of tasks}

How much of your working time do you spend on average conducting tasks in the following four categories? (Use the following scale to assess time spent: $1=$ none at all, 2 = very little, $3=$ moderately little, 4 = average, 5 = moderate, 6 = very much, 7 = extremely much)
a. Daily tasks (time horizon of $0-1$ month)
b. Operational tasks (time horizon of 1 month-1 year)
c. Tactical tasks (time horizon of 1-3 years)
d. Strategic tasks (time horizon of more than 3 years)

\section{Place of work}

How much of your working time do you spend on average in the following places? (Use the following scale to assess importance: see question 2)
a. Your own office
b. Elsewhere inside your firm
c. Business travel or business visits outside your firm
d. At home working for your firm
e. Elsewhere outside your firm

\section{The importance of different sectors of information}

How important do you consider the following sectors of information to your managerial work if they are available? (Use the following scale to assess importance: see question 1)

a. Financial perspective (financial performance, profitability, growth, liquidity, solvency)

b. Customer perspective (customer satisfaction, loyalty, customer relationships, product price, quality, markets)

c. Supplier perspective (quality of delivery, reliability, speed, elasticity)

d. Competitor perspective (aggressiveness, performance, strategy, products)

e. Employee perspective (employee motivation, satisfaction, elasticity, competence)

f. Internal processes perspective (process performance, through-put time, quality, reliability) 
g. Innovation and learning perspective (ability to innovate, develop, learn, and improve activities)

\section{The availability of different sectors of information}

How would you assess the availability of the following sectors of information in your managerial work? (Use the following scale to assess availability: 1 = not available at all, $2=$ very poor availability, 3 = moderately poor availability, $4=$ average availability, $5=$ moderately good availability, 6 = very good availability, 7 = extremely good availability)

(For the different perspectives, see question 4)

\section{Contextual variables}

a. Size: measured from financial statements)

b. Industry: What is the main industry sector of your firm? (Pick one: manufacturing, trade, service, construction, transport, other industry)

c. Generic strategy: How would you specify your firm's main generic strategy to achieve competitive advantage? (Pick one: Cost leadership: To produce products and services at the lowest prices, Differentiation: To produce clearly different and unique products and services, Focus: To focus on a narrow market niche, for example, a narrow customer group, narrow product line, or narrow geographical area)

d. Market strategy: How would you label your firm's main market strategy? (Pick one: Prospector: The firm is continuously investing in new markets and the development of new products and wants to be a pioneer in its business area, Defender: The firm is continuously defending its present market position and existing products and wants to improve its efficiency to produce existing products and services, Analyzer: The firm shares characteristics of a prospector and a defender and mirrors both types to some degree)

e. Perceived environmental uncertainty (PEU): What is the expected level of accuracy when you predict changes in the business environment of your firm for a 2-to-4-year horizon? (Pick one: $1=$ extremely low, $2=$ very low, $3=$ moderately low, $4=$ average, $5=$ moderately high, 6 = very high, $7=$ extremely high)

f. Competition: How would you assess the strength of competition in your business area? (Scale: see question 6.e.)

g. Decentralization (horizontal structure of organization): How would you assess the degree of decision-making decentralization in your firm at the moment? (Scale: see question 6.e.)

h. Decision-making levels (vertical structure of organization): How many different decision-making levels (e.g., top management, middle management, lower management, or supervisors) does your firm have? (Pick one: $1=$ extremely few, 2 = very few, $3=$ moderately few, 4 = average, 5 = quite many, 6 = very many, 7 = excessively many)

i. Orders (formality of organization): How important do you consider following the instructions of top management in your firm? (Scale: see question 1)

j. Is your firm a family firm (more than $50 \%$ of the firm is owned by family members)? (Pick one: $0=$ No, $1=$ Yes)

$\mathrm{k}$. Owner involvement in management: What is the degree of owners' involvement in the management of your firm? $0=$ no involvement at all, $100=$ management is entirely in the owners' hands. (Pick one: $1=0,2=1-20,3=21-40,4=41-60,5=61-80,6=81-99$, $7=100$ )

1. Export: How much has your firm exported as a percentage of sales on average during the last three years? (Pick one: $1=0,2=1-10,3=11-20,4=21-30,5=31-40,6=41$ $50,7=51-60,8=61-70,9=71-100)$ 


\section{Personal variables}

Please specify the following personal information:

a. Gender: What is your gender? (Pick one: male, female)

b. Age: How old are you? (Pick one: $1=<20,2=21-30,3=31-40,4=41-50,5=51-60,6=$ 61- years)

c. Management experience: What is the length of your experience in managerial work in general? (Pick one: $1=<5,2=6-10,3=11-15,4=16-20,5=21$ - years)

d. Education level: What is the level of your education? (Pick one: $1=$ primary school, $2=$ high school, 3 = lower vocational school degree, $4=$ higher vocational school degree, $5=$ lower university degree, 6 = higher university degree)

Appendix 2. Pearson correlations for the importance of managerial task variables and the crisisgroup dummy

\begin{tabular}{|l|l|l|l|l|l|l|}
\hline Variables & $\begin{array}{l}\text { Model } \\
1\end{array}$ & $\begin{array}{l}\text { p- } \\
\text { value }\end{array}$ & $\begin{array}{l}\text { Model } \\
2\end{array}$ & $\begin{array}{l}\text { p- } \\
\text { value }\end{array}$ & $\begin{array}{l}\text { Model } \\
3\end{array}$ & $\begin{array}{l}\mathrm{p}- \\
\text { value }\end{array}$ \\
\hline $\begin{array}{l}\text { 1. Role category importance measures } \\
\text { Average importance of all tasks }\end{array}$ & -0.173 & 0.043 & -0.163 & 0.087 & -0.188 & 0.047 \\
\hline Average importance of interpersonal role & -0.203 & 0.012 & -0.145 & 0.129 & -0.175 & 0.065 \\
\hline Average importance of informational role & -0.098 & 0.238 & -0.113 & 0.237 & -0.132 & 0.165 \\
\hline Average importance of decisional role & -0.172 & 0.040 & -0.165 & 0.084 & -0.183 & 0.054 \\
\hline 2. Role-ambiguity measures importance of 1-3 most & & & & & & \\
\hline $\begin{array}{l}\text { Average important tasks } \\
\text { importance of 1-5 most }\end{array}$ & -0.232 & 0.004 & -0.246 & 0.009 & -0.252 & 0.007 \\
\hline $\begin{array}{l}\text { Average important tasks } \\
\text { importan }\end{array}$ & -0.244 & 0.002 & -0.261 & 0.006 & -0.263 & 0.005 \\
\hline
\end{tabular}

Note:

Model 1: Pearson correlation with crisis-group dummy without control variables

Model 2: Pearson partial correlation with crisis-group dummy controlled for net sales in 2009,

focus-strategy dummy, defender-strategy dummy, centralization, level of education, and PEU

Model 3: Pearson partial correlation with crisis-group dummy controlled for net sales in 2009,

focus-strategy dummy, defender-strategy dummy, centralization, and level of education

Appendix 3. Pearson correlations for time horizon and place-of-work variables and the crisisgroup dummy

\begin{tabular}{|l|l|l|l|l|l|l|}
\hline Variables & $\begin{array}{l}\text { Model } \\
1\end{array}$ & $\begin{array}{l}\mathrm{p}- \\
\text { value }\end{array}$ & $\begin{array}{l}\text { Model } \\
2\end{array}$ & $\begin{array}{l}\mathrm{p} \text { - } \\
\text { value }\end{array}$ & $\begin{array}{l}\text { Model } \\
3\end{array}$ & $\begin{array}{l}\mathrm{p}- \\
\text { value }\end{array}$ \\
\hline 1. Time-horizon variables & & & & & & \\
\hline $\begin{array}{l}\text { Tasks for less than one month time } \\
\text { horizon }\end{array}$ & 0.107 & 0.185 & 0.088 & 0.345 & 0.145 & 0.118 \\
\hline $\begin{array}{l}\text { Tasks for one-month-to-one-year time } \\
\text { horizon }\end{array}$ & -0.107 & 0.184 & -0.095 & 0.307 & -0.099 & 0.287 \\
\hline $\begin{array}{l}\text { Tasks for one-year-to-three-year time } \\
\text { horizon }\end{array}$ & -0.214 & 0.007 & -0.097 & 0.299 & -0.188 & 0.041 \\
\hline Tasks for over-three-year time horizon & -0.204 & 0.011 & -0.071 & 0.447 & -0.171 & 0.063 \\
\hline
\end{tabular}




\begin{tabular}{|l|r|r|r|r|r|r|} 
2. Place-of-work variables & & & & & & \\
\hline CEO's own office & -0.221 & 0.005 & -0.159 & 0.087 & -0.172 & 0.062 \\
\hline Elsewhere inside CEO's firm & 0.184 & 0.025 & 0.173 & 0.063 & 0.151 & 0.103 \\
\hline $\begin{array}{l}\text { Business travel or visits outside CEO's } \\
\text { firm }\end{array}$ & 0.088 & 0.275 & 0.070 & 0.456 & 0.124 & 0.179 \\
\hline $\begin{array}{l}\text { Home doing remote work for CEO's } \\
\text { firm }\end{array}$ & 0.032 & 0.690 & 0.109 & 0.240 & 0.069 & 0.456 \\
\hline Elsewhere outside CEO's firm & 0.192 & 0.018 & 0.196 & 0.034 & 0.218 & 0.018 \\
\hline
\end{tabular}

Note:

Model 1: Pearson correlation with crisis-group dummy without control variables

Model 2: Pearson partial correlation with crisis-group dummy controlled for net sales in 2009 ,

focus-strategy dummy, defender-strategy dummy, centralization, level of education, and PEU

Model 3: Pearson partial correlation with crisis-group dummy controlled for net sales in 2009 ,

focus-strategy dummy, defender-strategy dummy, centralization, and level of education

Appendix 4. Pearson correlations for importance and availability of information from different sectors and the crisis-group dummy

\begin{tabular}{|l|r|r|r|r|r|r|}
\hline & $\begin{array}{l}\text { Model } \\
1\end{array}$ & $\begin{array}{l}\text { p- } \\
\text { value }\end{array}$ & $\begin{array}{l}\text { Model } \\
2\end{array}$ & p-value & \multicolumn{2}{l|}{$\begin{array}{l}\text { Model } \\
\text { Variables }\end{array}$} \\
\hline $\begin{array}{l}\text { Panel 1. Importance } \\
\text { information if available }\end{array}$ & & & & & \\
\hline Financial sector & -0.187 & 0.022 & -0.099 & 0.287 & -0.105 & 0.258 \\
\hline Customer sector & -0.186 & 0.023 & -0.180 & 0.053 & -0.221 & 0.016 \\
\hline Supplier sector & -0.109 & 0.184 & -0.061 & 0.511 & -0.098 & 0.293 \\
\hline Competitor sector & 0.003 & 0.974 & -0.003 & 0.978 & 0.005 & 0.959 \\
\hline Employee sector & -0.240 & 0.003 & -0.308 & 0.001 & -0.318 & 0.000 \\
\hline Internal processes sector & -0.253 & 0.002 & -0.262 & 0.004 & -0.302 & 0.001 \\
\hline Innovation and learning sector & -0.100 & 0.224 & -0.071 & 0.444 & -0.124 & 0.182 \\
\hline Panel 2. Availability of information & & & & & & \\
\hline Financial sector & -0.313 & 0.000 & -0.227 & 0.014 & -0.258 & 0.005 \\
\hline Customer sector & -0.284 & 0.000 & -0.211 & 0.023 & -0.252 & 0.006 \\
\hline Supplier sector & -0.175 & 0.033 & -0.091 & 0.330 & -0.144 & 0.120 \\
\hline Competitor sector & -0.095 & 0.250 & -0.013 & 0.891 & -0.088 & 0.341 \\
\hline Employee sector & -0.273 & 0.001 & -0.277 & 0.002 & -0.305 & 0.001 \\
\hline Internal processes sector & -0.166 & 0.044 & -0.120 & 0.198 & -0.151 & 0.104 \\
\hline Innovation and learning sector & -0.193 & 0.019 & -0.057 & 0.539 & -0.146 & 0.116 \\
\hline
\end{tabular}

Note:

Model 1: Pearson correlation with crisis-group dummy without

control variables

Model 2: Pearson partial correlation with crisis-group dummy controlled for net sales in 2009.

focus-strategy dummy, defender-strategy dummy, centralization, level of education, and PEU

Model 3: Pearson partial correlation with crisis-group dummy controlled 
for net sales in 2009,

focus-strategy dummy, defender-strategy dummy, centralization, and level of education

Appendix 5. Estimation results of logistic regression analysis with PEU as a predictor for crisisgroup dummy

Panel 1. Model Summary

\begin{tabular}{|l|r|}
\hline -2 Log Likelihood & 95.597 \\
\hline Cox \& Snell R Square & 0.272 \\
\hline Nagelkerke R Square & 0.431 \\
\hline Hosmer and Lemeshow test statistic & 3.75 \\
\hline p-value & 0.879 \\
\hline
\end{tabular}

Panel 2. Estimated logistic regression model

\begin{tabular}{|l|r|r|r|r|r|}
\hline Variables in the Equation & $\begin{array}{l}\text { B } \\
\text { coefficient }\end{array}$ & $\begin{array}{l}\text { Stand. } \\
\text { Error }\end{array}$ & $\begin{array}{l}\text { Wald } \\
\text { statistic }\end{array}$ & $\begin{array}{l}\text { p- } \\
\text { value }\end{array}$ & Exp(B) \\
\hline $\begin{array}{l}\text { Task 16. Hold strategy sessions when } \\
\text { problems arise that threaten section or } \\
\text { organization }\end{array}$ & -0.354 & 0.210 & 2.851 & 0.091 & 0.702 \\
\hline Time exceeding three years spent on tasks & -0.130 & 0.230 & 0.321 & 0.571 & 0.878 \\
\hline Working elsewhere inside the CEO's firm & 0.599 & 0.215 & 7.772 & 0.005 & 1.821 \\
\hline $\begin{array}{l}\text { Availability of employee-perspective } \\
\text { information }\end{array}$ & -0.597 & 0.267 & 4.994 & 0.025 & 0.551 \\
\hline $\begin{array}{l}\text { Availability of financial-perspective } \\
\text { information }\end{array}$ & -0.761 & 0.261 & 8.497 & 0.004 & 0.467 \\
\hline PEU & 0.839 & 0.301 & 7.755 & 0.005 & 2.314 \\
\hline Constant & 1.674 & 2.388 & 0.491 & 0.483 & 5.331 \\
\hline
\end{tabular}

Panel 3. Classification based on predicted probability (cut-off valu Predicted class:

\begin{tabular}{|l|r|r|}
\hline Original class: & Non-crisis firms & \multicolumn{2}{l|}{ Crisis firms } \\
\hline & & \\
Non-crisis firms & $76.79 \%$ & $23.21 \%$ \\
\hline Crisis firms & $25.00 \%$ & $75.00 \%$ \\
\hline Overall & & $76.43 \%$ \\
\hline
\end{tabular}

